\title{
The significance of magnesium for crop quality
}

\author{
Jóska Gerendás • Hendrik Führs
}

Received: 9 June 2012 / Accepted: 3 December 2012 / Published online: 9 January 2013

(C) The Author(s) 2013. This article is published with open access at Springerlink.com

\begin{abstract}
Background The quality of agricultural and horticultural products and its modulation by fertilization has increasingly received attention. However, whereas the importance of magnesium $(\mathrm{Mg})$ as an essential plant nutrient is well established, the impact of $\mathrm{Mg}$ nutrition on quality parameters has only been rarely addressed. Scope This review aims at evaluating the available knowledge on the influence of $\mathrm{Mg}$ on produce quality. A short discussion on the term quality as used in this review is followed by an overview of the various functions of $\mathrm{Mg}$ in plant metabolism in relation to quality aspects. Finally, the available literature on $\mathrm{Mg}$-associated effects on crop quality is critically surveyed. The question whether $\mathrm{Mg}$ application beyond yield optimum further improves crop quality is specifically addressed.

Conclusion Increasing Mg supply on Mg-deficient sites tends to increase the quality of agricultural crops, particularly when the formation of quality traits is dependent on Mg-driven photosynthesis and assimilate translocation within the plant. In fruits and vegetables, ratios of $\mathrm{Mg}$ to other nutrients like $\mathrm{Ca}$ and $\mathrm{K}$ were shown to be a more reliable indicator of the quality response than the Mg status alone. Moreover, it is concluded that $\mathrm{Mg}$ doses beyond those required for maximum yield rarely induce a further improvement of produce quality.
\end{abstract}

Responsible Editor: Ismail Cakmak.

J. Gerendás $(\bowtie) \cdot H$. Führs

$\mathrm{K}+\mathrm{S}$ KALI GmbH,

Bertha-von-Suttner-Str. 7,

34131 Kassel, Germany

e-mail: joska.gerendas@kali-gmbh.com
Keywords Carbon partitioning · Cation balance . Nutrient function · Physiology · External quality · Internal quality $\cdot$ Storage quality

\section{The term 'quality' and quality traits}

In the past food security and yield stability were the main challenges of agricultural and horticultural research, focussing on efficiency of crop production systems and its intensification. Quality aspects hardly received any attention. However, in the last decades the topic 'quality' moved into the focus of research. Reasons may be raising awareness of stakeholders and, at least in the developed countries, the high degree of self-sufficiency, reached today. Particularly in fruits and vegetables quality aspects attracted interest in recent years. Concerns related to quality are thereby not only dependent on the production measures available, but also on national and international developments in agricultural policy and increased competition in the markets due to globalisation processes (Huyskens-Keil and Schreiner 2003). Consumers often claim that the quality of food items plays a major role in their preference and decision making. At the same time they may have only a limited understanding of the traits underlying the desired quality parameters (van Rijswijk and Frewer 2008). In fact, along the entire supply chain stakeholders may have a different understanding of the term 'quality' (Huyskens-Keil and Schreiner 2003).

Therefore, to address the impact of production factors on the quality of agricultural and horticultural produce a 
common understanding and definition of quality terms and traits is required (Shewfelt 1999). Schuphan (1961) already defined the term 'quality' as the sum of all subjective and objective quality traits of food crops and proposed a classification into market quality, utilisation quality and biological quality. This and similar early definitions of food or product quality focused on product parameters and were widely used or taken as a basis by food chemists (Shewfelt 1999). Using such definitions the term quality is interpreted in a productoriented way. However, the term 'quality' is a multifaceted one. Consumers may relate the term 'quality' to features that cannot be determined on the product itself. Later, Kader (1998) defined quality as "the degree of excellence or superiority, which is a combination of attributes, properties, or characteristics that give each commodity value of its intended use". This definition already puts a stronger focus on the user perspective, even though it is still a quite product-oriented approach. In line with definitions given by Schuphan (1961) and Kader (1998) Huyskens-Keil and Schreiner (2003) categorised the product quality into (1) the market value, (2) the utilisation value, (3) the sensory value, (4) the nutritional and health value, (5) the ecological value, and (6) the imaginary value. Over the years the understanding of the term quality has changed from the former more product- and process-oriented evaluation of product quality to a more consumer-oriented one (Kramer and Twigg 1970; Shewfelt and Brückner 2000). Of course this has strong implications for new marketing strategies including the development of quality management systems (Huyskens-Keil and Schreiner 2003). Nowadays, a general definition of the term 'quality' is stated by DIN ISO 9,000 as "the totality of features and characteristics relevant to the ability of a product or service to fulfil its requirements" (International Organization for Standardization 2005). This points to the important consideration that any judgment on the quality of an item requires a scale that is based on predefined requirements, needs or expectations (user-oriented definition). According to this definition the quality of a final product is determined by the intended use and related expectations. For example, wheat could be used for manufacturing bread, biscuits, starch, beer and alcohol. All these intended uses have specific, often even conflicting quality criteria. Moreover, a holistic approach would even need to take the way of production and processing (e.g. organic farming) as well as religious considerations (e.g. halal, kosher) into account, even though the production process may not affect the analytical parameters of the product itself.

In a recent review Giusti et al. (2008), in view of market globalization, introduced the term 'total food quality', covering a wide range of aspects. Based on the fact that these quality aspects also extend to animal feed and industrial applications (e.g. cotton for fibre), the 'total crop quality' may be grouped and classified as follows:

- Organoleptic/sensory properties (appearance, colour, texture, juiciness, taste, and aroma)

- Safety (toxic compounds naturally present, inorganic, organic, and biological, hazardous contaminants)

- Nutritional value (available energy, concentration and composition of proteins, fatty acids, vitamins, antioxidants, minerals, the digestibility and bioavailability)

- Functional properties (suitability for processing and transformation e.g. physical and chemical measures like solubility, absorption, firmness, mainly of industrial interest)

- Service and stability (suitability for transport and storage, shelf-life)

- Healthiness (constituents with additional beneficial health effects, mostly referred to as bioactive compounds: prebiotic and probiotic compounds, flavonoids, carotenoids, vitamins, peptides, etc.)

- Psychological factors (convenience, price, ease of use, novelty, prestige, religious and ethical considerations)

Depending on the intended use of a product and its position in a supply chain different quality aspects may appear important or negligible or their importance may change along the supply chain (Shewfelt and Brückner 2000; Huyskens-Keil and Schreiner 2003). Good examples are industrial crops like sugar beet and sugar cane. In such crops, the target constituent, in this case the sugar concentration (equivalent to the nutritional value), may be hardly affected by a specific production measure but constituents interfering with the recovery of the sugar (equivalent to functional properties), namely alpha-amino N, K or Na (Buchholz et al. 1995; Barlog et al. 2002) are likely to be affected. Hence, in this review the concentration of target and interfering constituents is treated as a quality trait. In contrast, in crop science the concentration of a target constituent (sugar, oil) is typically regarded a yield component. 
A given production factor may influence several parameters of yield and quality, partly with conflicting outcome (Marschner 2012). For example, with increasing $\mathrm{N}$ supply crop yield may respond in a similar way as does the crop quality, which particularly applies to the size of the harvested organ in planted vegetables bearing one target organ per plant (Wiesler et al. 2003). On the other hand the best quality may be achieved at a lower $\mathrm{N}$ input as required for maximum yield, as observed regarding the concentration of ascorbic acid (e.g. in broccoli, Brassica oleracea L. var. botrytis L., Xu et al. 2010), and nitrate in vegetables (Greenwood and Hunt 1986), while a $\mathrm{N}$ input beyond the level required for maximum yield improves the baking quality of wheat (McKenzie et al. 2006), and the concentration of B vitamins and carotenoids in vegetables (Mozafar 1993). The conflicting response of yield and quality traits of potato (Solanum tuberosum L.) to increasing $\mathrm{Mg}$ supply may serve as an example and is illustrated in Fig. 1. Whereas the yield maximum is reached at moderate $\mathrm{Mg}$ supply, most quality traits respond favourably to higher Mg levels. However, in the underlying studies used here the concentration of toxic glycoalkaloids is also increased by increasing Mg supply.

Magnesium as such represents an important nutrient in the human and animal diet, and food and feed often do not provide sufficient quantity. However, the significance of $\mathrm{Mg}$ as a nutritional component in food and feed is not covered in this article, and the interested reader should consult recent reviews on the subject (White and Broadley 2009; Broadley and White 2010; Lean et al. 2006; Rosanoff 2012).

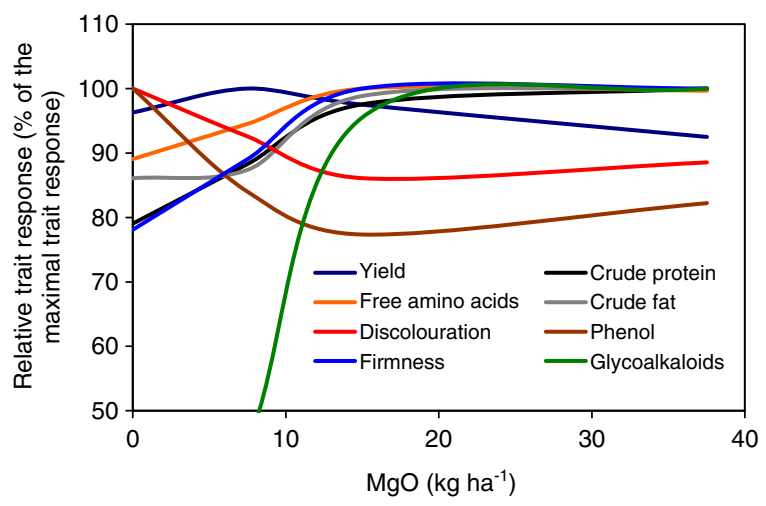

Fig. 1 Yield and quality parameters as affected by the $\mathrm{Mg}$ supply to potato (schematically). For each parameter displayed in the graph the values were calculated relative to their maximal expression (= $100 \%$ ) to $\mathrm{Mg}$ supply (based on: Evans and Mondy 1984; Klein et al. 1982; Klein et al. 1981)

\section{Functions of $\mathrm{Mg}$ in plant metabolism}

Magnesium in carbohydrate formation

Photosynthesis as the central process for crop production depends on the plant's Mg status in several respect. Efficient carbohydrate formation requires high light interception by the light harvesting complexes (LHCs) attached to the photosystems I and II (PSI, PSII). Magnesium as the central atom is an essential constituent of chlorophyll $a / b$, which in turn is part of these LHCs. Due to the complex roles of $\mathrm{Mg}$ in chlorophyll and protein biosynthesis severe $\mathrm{Mg}$ deficiency results in interveinal chlorosis of older and fully mature leaves as $\mathrm{Mg}$ is highly mobile within the plant (Marschner 2012). Negative impacts of an impaired primary (energy) metabolism are to be expected not only on crop yield (Grzebisz 2013), but also on crop quality parameters.

The share of the total $\mathrm{Mg}$ bound to chlorophyll depends on the $\mathrm{Mg}$ status and ranges from about 6 to $25 \%$ and highest values are found in Mg-deficient plants (Marschner 2012) indicating that it's not the $\mathrm{Mg}$ bound to chlorophyll that is limiting its synthesis under Mg-deficient conditions. Another $5-10 \%$ is firmly bound to cell wall pectins and sparingly soluble salts in the vacuole. The remaining fraction fulfils further roles in plant physiology, some of which are also associated with photosynthesis: In contrast to the function of $\mathrm{Mg}$ in light interception these additional aspects are related to the charge and high transmembrane mobility of $\mathrm{Mg}^{2+}$. After charge separation at the LHC-photosystem complexes and the subsequent electron transport through the PS the development of a significant $\mathrm{pH}$ gradient across the thylacoids (around $\mathrm{pH} 8$ in the stroma, around $\mathrm{pH} 5$ in the thylakoid lumen) is associated with dissipation of the electrical potential by channel-mediated transmembrane transport of $\mathrm{Mg}^{2+}$ from the lumen to the stroma. This allows establishing the proton motive force facilitating the ATPase-mediated $\mathrm{H}^{+}$influx into the lumen resulting in ATP synthesis (Marschner 2012; Shaul 2002 and literature cited therein). The $\mathrm{pH}$ rise in the stroma upon illumination is also required for efficient $\mathrm{CO}_{2}$ assimilation in the light-independent part of the photosynthesis as the $\mathrm{CO}_{2}$-fixing enzyme (Ribulose-1,5bisphosphate Carboxylase/Oxygenase, RuBisCO) requires a basic $\mathrm{pH}$ for optimal function (Portis Jr. et al. 1986). In addition, the high $\mathrm{Mg}$ concentration accumulating in the stroma due to trans-thylakoid $\mathrm{Mg}$ 
transport for reasons of charge-balance is also essential as cofactor for $\mathrm{RuBisCO}$, as binding of $\mathrm{Mg}^{2+}$ to the enzyme is required for its full activation (Sugiyama et al. 1969; Taylor and Andersson 1996). As all these functions of $\mathrm{Mg}$ are more sensitive to the $\mathrm{Mg}$ status as the chlorophyll formation itself, the light energy that continues to be absorbed under conditions of latent $\mathrm{Mg}$ deficiency is not consumed in a safe way, giving raise to a higher sensitivity of $\mathrm{Mg}$-deficient tissue to high light intensities (Cakmak and Kirkby 2008).

\section{Magnesium in carbohydrate partitioning}

As several plant organs (roots, fruits, buds) are not able to meet their demand for assimilates (energy) directly photosynthates and metabolites synthesised thereof (sugars, amino acids etc.) are translocated by a directed, demanddriven source-to-sink transport. This is particularly critical for those crops storing substantial fractions of the total plant biomass as carbohydrates or oils in tubers, bulbs, and grains. Particularly for these crops efficient formation of high quality produce strongly depends on unrestricted and sufficient Mg availability (Grzebisz 2013). Currently three phloem loading types are discussed with two active, energy consuming ones and one passive loading type (Turgeon 2010): Phloem loading as an energy consuming process involves formation of electrochemical gradients by $\mathrm{H}^{+}$-ATPases and subsequent $\mathrm{H}^{+}$-sucrose co-transport into the phloem. Energy is provided by Mg-ATP, the complex formed from $\mathrm{Mg}^{2+}$ and ATP under physiological conditions, which improves the binding of ATP to the enzymes requiring ATP. Indeed, it was shown for mung bean that about $90 \%$ of the total cytoplasmic Mg concentration is complexed with ATP, whereas the remaining $\mathrm{Mg}$ is regarded as free $\mathrm{Mg}$ (Yazaki et al. 1988; Shaul 2002). However, even though not yet fully understood, it appears that apart from its role in Mg-ATP formation, $\mathrm{Mg}$ may play additional direct or indirect crucial roles in phloem loading (Cakmak and Kirkby 2008 and literature cited therein).

The role of magnesium for functional nucleic acid and protein biosynthesis

Nucleic acids are of pivotal importance for any living organism and play diverse roles in plant metabolism. Magnesium is involved in stabilizing conformational structures of the nucleic acids needed for proper functionality. Moreover, nucleic acid-synthesizing polymerases and degrading nucleases require $\mathrm{Mg}$ as well (Sreedhara and Cowan 2002).

Ribosomes are macromolecular structures formed from protein and ribonucleic acids responsible for protein biosynthesis. The active form of ribosomes requires aggregation of two subunits, necessitating $\mathrm{Mg}$ to form a bridge between the subunits. Hence, protein biosynthesis is strongly reduced under $\mathrm{Mg}$ deficiency leading to increased concentrations of the precursor amino acids (Marschner 2012; Fischer et al. 1998).

Magnesium - its function as mobile ion

The majority (60-90\%) of the $\mathrm{Mg}$ in well-supplied plants is extractable with water (Finck 1992). The 'metabolic Mg pool' is mainly located in the cytoplasm and the chloroplasts. This pool is subject to strict regulatory processes specifically adapted to the actual metabolic needs, while using the vacuole as a storage compartment for Mg. The demand for 'metabolic' Mg can thereby be satisfied and maintained through import/export of $\mathrm{Mg}$ from the vacuole (Marschner 2012). Evidence was presented that the transport across the tonoplast is facilitated by $\mathrm{Mg}^{2+} / \mathrm{H}^{+}$exchangers (AtMHX, Shaul et al. 1999). In addition, $\mathrm{Mg}$ serves (together with $\mathrm{K}$ ) as cation in the regulation of the cation-anion balance and as osmotically active ion in turgor regulation of cells (Marschner 2012). Especially the vacuole as storage compartment for myriads of minerals and metabolites is responsible for various quality aspects of sugar crops, fruits and vegetables.

\section{Mg deficiency and Mg excess}

As described, a plant well-supplied with $\mathrm{Mg}$ and subjected to deficiency conditions can initially count on a considerable pool of mobile $\mathrm{Mg}$. Under proceeding deficiency, however, all physiological processes described here are impaired. Hence, it is obvious that the Mg status not only affects the mineral but also the metabolite pools, thereby influencing various quality parameters as discussed in the section below.

There is no evidence available on the direct effect of excessive Mg supply on plant metabolism. However, since direct $\mathrm{Mg}$ toxicity has not been observed (and which might not be expected due to its roles in plant physiology) impairments in the plant's physiology might be merely related to nutrient imbalances in planta, e.g. K, Ca and Mn, particularly when considering 
the antagonistic effects of imbalanced supply of cationic nutrients $\left(\mathrm{K}, \mathrm{NH}_{4}, \mathrm{Ca}, \mathrm{Mg}\right.$ ) (see Review by Gransee and Führs 2013).

\section{Mg effects on crop quality}

General comments

Wherever possible, only experiments using fully soluble $\mathrm{Mg}$ sources are included in order to avoid misleading interpretations resulting from $\mathrm{Mg}$ sources of limited availability (dolomite and magnesite) and to avoid secondary liming effects on nutrient dynamics and disease resistance.

\section{Agricultural crops}

\section{Cereals}

Surprisingly few studies on the significance of $\mathrm{Mg}$ for product quality of cereals grown under field conditions were published, whereas a positive impact of $\mathrm{Mg}$ on grain yield of field-grown cereals was frequently reported (Beringer and Forster 1981; Grzebisz 2013). But what are quality traits in cereals? On the one hand the single grain mass, often referred to as the 1,000grain weight, represents an important yield component that heavily depends on carbohydrate translocation during grain filling (Marschner 2012; Grzebisz 2013). On the other hand the single grain mass represents an important technological quality parameter (functional property) as the milling efficiency when producing superfine flour depends on the endosperm to bran ratio and thus on grain size (Greffeuille et al. 2006). In brewing barley the volume weight is also considered as quality parameter (Verma et al. 2008).

Early indications of marked increases in the starch concentration of rye (Secale cereale L.) grain resulting from $\mathrm{Mg}$ addition to acidic soddy-podzolic, sandyloamy soils were observed by Magnitskii et al. (1970). Moreover, Al'shevskii and Derebon (1982) reported that in winter wheat (Triticum aestivum L.) grown on Mg-deficient soil with basal NPK dressing increasing $\mathrm{Mg}$-sulphate application in spring increased the 1,000-grain weight. Also Beringer and Forster (1981) documented in pot-grown barley an increase in the 1,000-grain weight with increasing seed $\mathrm{Mg}$ status up to $0.1 \% \mathrm{Mg}$ in the grain. The increase in the 1,000-grain weight was accompanied by a stronger accumulation of phytates, the $\mathrm{Ca}$ and $\mathrm{Mg}$ salts of phytic acid. This accumulation of phytates was particularly obvious at high $\mathrm{Mg}$ status beyond the level required for maximum yield. Phytates are known for their negative effects on the intestinal absorption of $\mathrm{Mg}$ (Bohn et al. 2004) and trace nutrients (Gibson et al. 2010). However, recent reports indicate beneficial effects of dietary phytates such as lowering blood glucose and lipid levels, and their antioxidative and anticancerogenic activities (Schlemmer et al. 2009).

The impact of $\mathrm{Mg}$ on quality traits may also occur indirectly, e.g. through improving the nutritional status of the crop. Ding et al. (2006) described the significance for $\mathrm{Mg}$ in $\mathrm{N}$ nutrition, and it may be hypothesized that an improved $\mathrm{N}$ metabolism results in enhanced $\mathrm{N}$ assimilation with improved $\mathrm{Mg}$ status (Grzebisz 2013). Indeed, Al'shevskii and Derebon (1982) reported increased concentrations of crude protein and raw gluten in the grains in response to $\mathrm{Mg}$ sulphate application in field-grown winter wheat. An increase in the protein concentration of rye grain resulting from $\mathrm{Mg}$ addition to acidic soddy-podzolic, sandy-loamy soils was also reported by Magnitskii et al. (1970). This agrees well with pot experiments investigating spring barley as reported by Fecenko and Francakova (1980). In these experiments Mg fertilization had no clear effect on total $\mathrm{N}$ concentration, but reduced the share of soluble $\mathrm{N}$ on the total $\mathrm{N}$ concentration in the grains particularly when supplied as $\mathrm{MgSO}_{4}$. In more recent studies the interaction of $\mathrm{N}$ and $\mathrm{Mg}$ supply on yield and quality parameters of winter wheat grown in $\mathrm{K}$-rich, Mg-deficient soil was specifically addressed (Chwil 2001, 2009). When pooled over the two $\mathrm{N}$ rates tested, the addition of $\mathrm{MgSO}_{4}$ significantly increased the grain concentration of crude protein and gluten (Fig. 2). Even though a positive effect regarding grain yield and protein concentration was realized by high $\mathrm{N}$ supply, highest yields were only achieved when $\mathrm{Mg}$ was applied in the highest rates at the respective $\mathrm{N}$ rates.

\section{Potato (Solanum tuberosum L.)}

As compared to cereals effects of $\mathrm{Mg}$ on potato quality were more frequently reported, and the well-known interaction of Mg and K (Marschner 2012) was particularly frequently addressed (Cepl 1994; Allison et al. 2001; Zengin et al. 2008). However, the quality of 


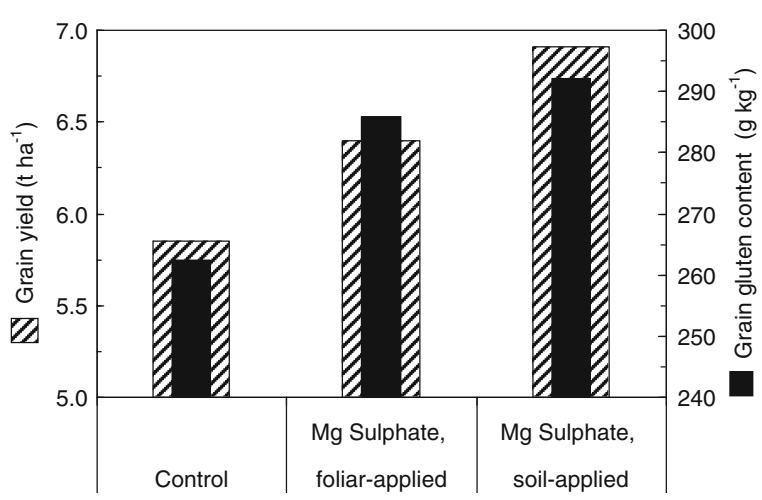

Fig. 2 The effect of $\mathrm{Mg}$ on yield and grain gluten concentration of winter wheat $\left(\mathrm{LSD}_{0.05}\right.$ for grain yield and gluten concentration were $0.36 \mathrm{tha}^{-1}$ and $14.7 \mathrm{gkg}^{-1}$, respectively; based on Chwil 2001, 2009)

potatoes is a complex parameter and the desired quality traits depend on the intended usage (Hiltrop 1999; Talburt and Smith 1987). For warehouse potatoes (fresh consumption) among external quality parameters also the cooking type (floury or mealy, medium, waxy or hard-boiling) are important. The cooking type is merely controlled by genetic factors, but manipulating the growth conditions can have an important impact as well. For example, conditions enhancing assimilation and translocation of carbohydrates tend to increase the starch content and thus the mealiness of the cooked potato. Both starch content and mealiness are positively correlated with the specific gravity and the dry matter content (Smith 1977; Talburt and Smith 1987; Feltran et al. 2004), an important measure for potato quality. For starch production the starch concentration in the tubers obviously is the most important quality criterion. The dry matter content itself represents an important quality criterion when producing potatoes for further processing such as French fries, crisps or dry instant products. High dry matter contents ensure lower oil absorption (resulting in more product per unit oil) and improve texture and shape of the product (Lulai and Orr 1979; Hiltrop 1999; Feltran et al. 2004). Therefore, due to the importance of $\mathrm{Mg}$ for photosynthesis and assimilate translocation, a strong effect on the quality of potatoes particularly for industrial use is anticipated.

Another important quality trait is tuber firmness or resistance against mechanical stresses occurring during harvest, transport and storage. In early studies it was demonstrated that mechanical resistance of potato tubers significantly correlates with specific gravity and texture
(Lujan and Smith 1964). Consequently it was concluded that a firmer potato should exhibit a mealier texture (as realized by higher starch contents) associated with better baking and processing qualities. Increased firmness also reduces the risk of bruising and various forms of discolourations (see section below). Indeed, Klein et al. (1982) reported that increasing $\mathrm{Mg}$ supply $(0-115 \mathrm{~kg}$ $\mathrm{MgSO}_{4} \mathrm{ha}^{-1}$ ) increased the firmness of Katahdin potatoes grown in soil that was not nutrient-deficient. Later, Cepl (1994) observed a consistent response of the yield and starch concentration of a late industrial variety to $\mathrm{Mg}$ application (40 and $80 \mathrm{kgMgha}^{-1}$ ) as compared to $\mathrm{Mg}$ control treatment, whereas an early-maturing warehouse variety exhibited less consistent responses. In 3year field experiments using two mid-early cultivars Poberezny and Wszelaczynska (2011) observed that increasing $\mathrm{Mg}$ supply $\left(0-100 \mathrm{kgMgOha}^{-1}\right.$ as $\left.\mathrm{MgSO}_{4}\right)$ consistently increased dry matter and starch concentration. Zengin et al. (2008) investigated the effects of K and $\mathrm{Mg}$ supply on potato quality over 2 years at two different locations. However, in six out of eight treatment combinations suitable to assess the effect of $\mathrm{Mg}$ supply no significant response of the dry matter content was apparent. The remaining two treatment combinations even showed significantly contrasting responses making a proper evaluation difficult. From these studies, at least in tendency, an overall positive effect of $\mathrm{Mg}$ on mechanical resistance due to starch and therefore dry matter accumulation can be expected.

Potatoes for both fresh consumption and for industrial processing are stored for considerable durations. Hence, storage losses due to respiration and pathogen attack often cause severe economic losses, and hence the storage properties of potato tubers received much attention (Affleck et al. 2012). The effect of $\mathrm{N}$ and $\mathrm{K}$ supply on storage properties of potato tubers was studied intensively (e.g. Kolbe et al. 1995), whereas this holds not true for the nutrient Mg. However, in a recent study Wszelaczynska and Poberezny (2011) showed that intermediate $\mathrm{Mg}$ doses ranging from 0 to $100 \mathrm{~kg} \mathrm{MgOha}^{-1}$ (optimum $60 \mathrm{~kg} \mathrm{MgO} \mathrm{ha}{ }^{-1}$ ) reduced fresh weight losses during storage for 6 months in two mid-early cultivars. For $\mathrm{K}$ a similar response was observed (range $0-240 \mathrm{kgK}_{2} \mathrm{Oha}^{-1}$, optimum $160 \mathrm{kgK}_{2} \mathrm{Oha}^{-1}$ ), whereas $\mathrm{N}$ supply negatively affected fresh weight losses during storage. Interestingly, fresh weight losses were accompanied by dry matter and starch losses (Poberezny and Wszelacrzynska 2011, Wszelacrzynska and Poberezny 2011) indicating that 
the storage losses observed in that experiment included losses due to respiration. However, the underlying physiological mechanisms remain to be elucidated.

Discolourations of various origins represent important quality criteria in potato. The so-called black spot incidence and crude pulp discolouration are a result of enzymatic processes after damaging (e.g. harvest, transport) or processing (crude pulp) of potatoes. Damaging and processing of potato tubers allows polyphenol oxidases to act on free phenolic compounds (e.g. phenolic amino acids) leading to the formation of dark melanins (Muneta 1981). Early reports on the effect of $\mathrm{Mg}$ fertilization on enzymatic discolouration have been provided by Mulder (1949). Unfortunately, available results are not consistent. For example, Klein et al. (1981) found that fertilization with $\mathrm{MgSO}_{4}$ reduced enzymatic discoloration and concentration of phenolics, whereas the crude lipid and phospholipid contents of potato tubers were increased. A study by Mondy et al. (1967) indicated that especially the concentration of phenolic compounds of tubers positively correlated with enzymatic discoloration. However, enzymatic discoloration of potato was shown to be inversely related to the lipid content (Mondy et al. 1965; Mondy and Koch. 1978). The contradictory results indicate that interactions with other production measures and storage time may have masked the effect of $\mathrm{Mg}$. Based on these reports it is difficult to draw conclusions as to the involvement of $\mathrm{Mg}$ in the quality response. The enzymatic cascade finally leading to melanin formation is inhibited by low $\mathrm{pH}$ and antioxidants. Consequently, the addition of citric and/or ascorbic acid can reduce or prevent such enzymatic discolourations. Indeed, particularly the content of ascorbic acid represents a quality criterion in its own right (Delgado et al. 2001). Synthesis of ascorbic acid originates from glucose (Marschner 2012) and a positive influence of favourable environmental conditions for photosynthesis (high light intensity) on ascorbic acid concentrations in various crops has frequently been reported (e.g. Noctor and Foyer 1998). In view of the significance of $\mathrm{Mg}$ for assimilation and carbohydrate translocation a positive effect of improved Mg supply may be expected. Indeed, Rubanov and Voitova (1970) observed an enhanced accumulation of ascorbic acid in response to increased $\mathrm{Mg}$ supply. However, contrasting results on the impact of $\mathrm{Mg}$ on ascorbic acid contents were reported. Mondy and Ponnampalam (1986) did not observe significant effects of increasing $\mathrm{Mg}$ supply on the concentration of ascorbic acid, which agrees with early reports by Karikha et al. (1944). It may be concluded that the contrasting results on phenol and ascorbic acid contents in combination with the occurrence of black spot incidence are at least somewhat interrelated, as all these parameters are associated with several environmental stress factors that were not controlled in the field experiments referred to.

In deep-fried potato products another nonenzymatic type of discolouration occurs that is closely related to the presence of reducing sugars. Under dry heat conditions the so-called Maillard reaction of reducing sugars with amino $\mathrm{N}$ compounds forms brown deposits (Mottram et al. 2002; Gerendás et al. 2007). Moreover, when reducing sugars react with asparagine intermediates may form acrylamide, which is being considered 'likely carcinogenic for humans' (Mottram et al. 2002). To our knowledge no results were published yet on the effect of $\mathrm{Mg}$ nutrition of potatoes on the content of reducing sugars, asparagine or acrylamide formation, even though an effect can be expected considering the $\mathrm{Mg}$ function in protein biosynthesis and carbohydrate partitioning. Future studies are necessary to clarify this point.

Another group of compounds found in potatoes, the glycoalcoloids, are of particular interest due to their negative impact on human health. Hence, the concentration of glycoalkaloids (e.g. alpha-solanine and alpha-chaconine) in tubers as quality trait in potato has received considerable attention. These alkaloids impart a bitter flavour to potatoes (Sinden et al. 1976), and most importantly they are toxic to humans (McMillan and Thompson 1979). Furthermore, accumulation of glycoalkaloids was associated with the greening of tubers (Maga and Fitzpatrick 1980), although a direct link between the two processes has not been proven (Gull and Isenberg 1960). However, it has to be stated here that in recent years positive bioactive properties were also attributed to this group of compounds (see Milner et al. 2011, for review). The toxicity of these alkaloids, the positive response of their concentration in stems and leaves to increasing N supply (Love et al. 1994; Rogozinska and Wojdyla 1999), and the significance of $\mathrm{Mg}$ for $\mathrm{N}$ metabolism has prompted several investigators to study the influence of Mg supply on glycoalkaloid accumulation in potato tubers. Mondy and Ponnampalam (1985) observed a significant increase of the glycoalkaloid 
concentration in tubers ( 17 vs. $\left.9 \mathrm{mg} 100 \mathrm{~g}^{-1} \mathrm{FM}\right)$ after application of $56 \mathrm{kgMgO}$ per ha. This principally agrees with earlier reports of Evans and Mondy (1984) based on 2-year field experiments showing a significant increase of total glycoalkaloid content of tubers at all levels of fertilization $\left(0-112 \mathrm{kgha}^{-1}\right)$. The authors suggested that the increase in chlorophyll synthesis, the stimulation of sugar metabolism and/or the increase in amino acid production may be involved in this effect. Indeed, in reports referring to the same field experiments it was reported that $\mathrm{Mg}$ application increased both the total $\mathrm{N}$ and protein concentration (Mondy and Ponnampalam 1985; Klein et al. 1982). The maximal total amino acid concentration was observed at $45 \mathrm{~kg} \mathrm{MgOha}^{-1}$. At this $\mathrm{Mg}$ dose the total glycoalkaloid concentration also approached maximum levels (Evans and Mondy 1984). However, more recent studies by Rogozinska and Wojdyla (1999) based on 3-year field experiments showed no influence of $\mathrm{Mg}$ supply on glycoalkaloid concentration of potato tubers. These contrasting results show the need for further studies of the modulation of glycoalkaloid formation by Mg supply.

\section{Sugar beet (Beta vulgaris L. ssp. vulgaris)}

For sugar beet the extraordinary role of $\mathrm{Mg}$ for photosynthesis and assimilate translocation was highlighted by Hermans et al. $(2004,2005)$. Due to these roles a substantial increase in the sugar concentration of beet roots by $\mathrm{Mg}$ fertilization may be anticipated. As already described, in this review the term quality includes not only the concentration of a target ingredient but also the concentration of constituents interfering with its recovery. In sugar beet not only the sugar concentration is discussed but also the molasses forming substances $\mathrm{K}$ and $\mathrm{Na}$, as well as alpha-amino N compounds (Buchholz et al. 1995).

Results on the effects of Mg fertilization on the beet root sugar concentration appear inconsistent. Villarias et al. (2000) observed an increase of the beet root sugar concentration from 13.6 to $16.9 \%$ in response to increasing $\mathrm{Mg}$ soil application $\left(0-40 \mathrm{~kg} \mathrm{Mgha}^{-1}\right)$. In contrast, Allison et al. (1994) conducted a metaanalysis of 14 field experiments carried out at different sites in the UK. From this evaluation they concluded that "effects [of $\mathrm{Mg}$ soil application] on processing quality were inconsistent and unlikely to be of agronomic or economic significance". In other earlier studies Mg soil application only in tendency increased the sugar concentration of beet root (Draycott and Farley 1971). Strnad and Javurek (1991) observed a (non-significant) decrease of the sugar concentration in response to $\mathrm{MgSO}_{4} \cdot \mathrm{H}_{2} \mathrm{O}$ (kieserite) application $\left(120 \mathrm{~kg} \mathrm{Mgha}^{-1}\right)$. More recently, Szczepaniak et al. (2002), Barlog et al. (2002) and Barlog and Grzebisz (2004) also observed contrasting responses of the sugar concentration and technological quality of beet root to increasing Mg supply.

Foliar application of $\mathrm{Mg}$ was also shown to be effective in improving quality traits of sugar beet. Moustafa and Omran (2006) observed that foliar spray with Mg-sulphate solutions increased the sugar concentration and improved several technological parameters (Table 1). Similar observations were reported by Osman (2005) and El-Sayed (2005). Kristek et al. (2003) reported that foliar spray with $5 \% \mathrm{MgSO}_{4}$ • $7 \mathrm{H}_{2} \mathrm{O}$ (Epsom salt) increased the total sugar concentration from 14.8 to $15.5 \%$ and the recoverable sugar concentration from 12.32 to $12.95 \%$ (mean of 3 years). In an earlier report Kristek et al. (2000) observed a small, but significant increase of the sugar concentration of beet root upon foliar application of $5 \%$ Epsom salt solution. However, in absolute terms the positive effect of $\mathrm{Mg}$ fertilization on sugar concentration and recovery was quite small, which is further underlined by other investigators reporting no significant improvement of beet root quality upon foliar Mg fertilisation (Gutmanski et al. 1998).

A comparison of different trials in different years is difficult as a number of different factors predominantly influence the sugar concentration and extractability. It appears that whereas the importance of $\mathrm{Mg}$ for sugar formation and accumulation in the beet root is clarified, more information on the response of sugar beet under varying field conditions, particularly with respect to radiation and periodic drought, is highly sought after.

\section{Oil crops}

The global demand for vegetable oil has substantially increased during the last decades, which could principally be accomplished by increasing the acreage of oil crops, and increasing their yield. However, the possibility to increase the oil concentration deserves specific attention, particularly in view of increased profitability. Hence the following oil crops are specifically addressed 
Table 1 Influence of foliar $\mathrm{Mg}$ application on sugar concentrations and selected technological parameters of sugar beet (based on Moustafa and Omran 2006)

\begin{tabular}{lllllll}
\hline Treatment & $\begin{array}{l}\text { Sucrose } \\
(\%)\end{array}$ & $\begin{array}{l}\mathrm{K} \\
(\mathrm{mmol}\end{array}$ & $\begin{array}{l}\mathrm{Na} \mathrm{g}^{-1} \\
\text { beet root })\end{array}$ & $\begin{array}{l}\text { Alpha-amino } \mathrm{N} \\
(\%)\end{array}$ & $\begin{array}{l}\text { Extractable sugar } \\
(\%)\end{array}$ \\
\hline Control & 15.2 & 5.06 & 1.68 & 1.93 & 91.3 & 12.6 \\
$0.25 \% \mathrm{MgSO}_{4}$ & 15.6 & 5.08 & 1.68 & 1.85 & 91.5 & 13.1 \\
$0.5 \% \mathrm{MgSO}_{4}$ & 16.0 & 5.14 & 1.65 & 1.73 & 91.8 & 13.6 \\
$\mathrm{LSD}_{0.05}$ & 0.32 & 0.37 & n.s. & 0.17 & 0.27 & 0.3 \\
\hline
\end{tabular}

with respect to the impact of $\mathrm{Mg}$ fertilization on oil concentration of the harvest organ.

Oil palm (Elaeis guineensis Jacq.) In oil palm the harvested organ is the inflorescence (bunch). The most common quality measure is the so-called oil to bunch ratio. In agreement with the role of $\mathrm{Mg}$ for providing energy-rich carbohydrate compounds several studies revealed a significant increase of yield and oil to bunch ratio in oil palm. Tayeb (2005) reported an increase in the oil to bunch ratio by 1 and $1.8 \%$ after application of 0.4 and $0.8 \mathrm{kgMgOpalm}^{-1} \mathrm{a}^{-1}$, respectively, in form of kieserite in long-term (6 years) experiments conducted in Malaysia. This effect was largely due to a significant increase in the oil to dry mesocarp ratio and in the oil to fibre values. In tendency similar observations, also based on long-term experiments carried out in Malaysia, were reported by Tang et al. (2001) (Fig. 3).

Early experiments carried out in the Ivory Coast already highlighted the well-known interaction of $\mathrm{Mg}$ with $\mathrm{K}$ supply. Field experiments running for 2 years with two and four rates of $\mathrm{Mg}$ and $\mathrm{K}$, respectively, revealed that $\mathrm{Mg}$ application $\left(0.135 \mathrm{kgpalm}^{-1} \mathrm{a}^{-1}\right)$ decreased the oil to bunch ratio at $\mathrm{K}$ rates $\leq 0.9 \mathrm{kgK}_{2} \mathrm{Opalm}^{-1} \mathrm{a}^{-1}$, whereas this ratio increased at higher, more adequate $\mathrm{K}$ application rates (Ochs and Ollagnier 1977). Unfortunately no information was given on the soil $\mathrm{K}$ and $\mathrm{Mg}$ contents, so that it is not possible to ascribe the quality reductions to $\mathrm{K}$ and/or $\mathrm{Mg}$ directly. In view of the fact that oil palm is typically grown on acidic soils inadequate base cation contents might be expected. Hence, in this study the oil to bunch ratio negatively reacted to a $\mathrm{Mg}$ dominated nutrition of the palm indicating the need for a balanced nutrition of this crop also addressing the $\mathrm{K}$ requirement. Interestingly, in this study the fatty acid composition was also evaluated. However, as compared to the control, $\mathrm{Mg}$ application did neither affect the fatty acid composition nor the associated iodine value.

Brassica oil crops The Brassica species represent an important, genetically diverse group of oil crops used both in temperate and tropical regions. Given its global significance the number of investigations on the impact of $\mathrm{Mg}$ published in scientific journals is surprisingly limited. Jahangir et al. (2005) applied different rates of $\mathrm{Mg}\left(0,7.5,15\right.$ and $\left.30 \mathrm{kgha}^{-1}\right)$ to Indian mustard (Brassica juncea (L.) Czern.) and evaluated the impact on yield and oil quality. Even though the authors reported yield increases due to $\mathrm{Mg}$ supply, these differences were insignificant. However, the oil
Fig. 3 Effect of application of kieserite $\left(\mathrm{MgSO}_{4} \cdot \mathrm{H}_{2} \mathrm{O}\right.$; $27 \% \mathrm{MgO}$ ) on yield of fresh fruit bunches (FFB, left) and oil content indices (right). Treatment effects ( $F$-test) were not significant (based on Tang et al. 2001)
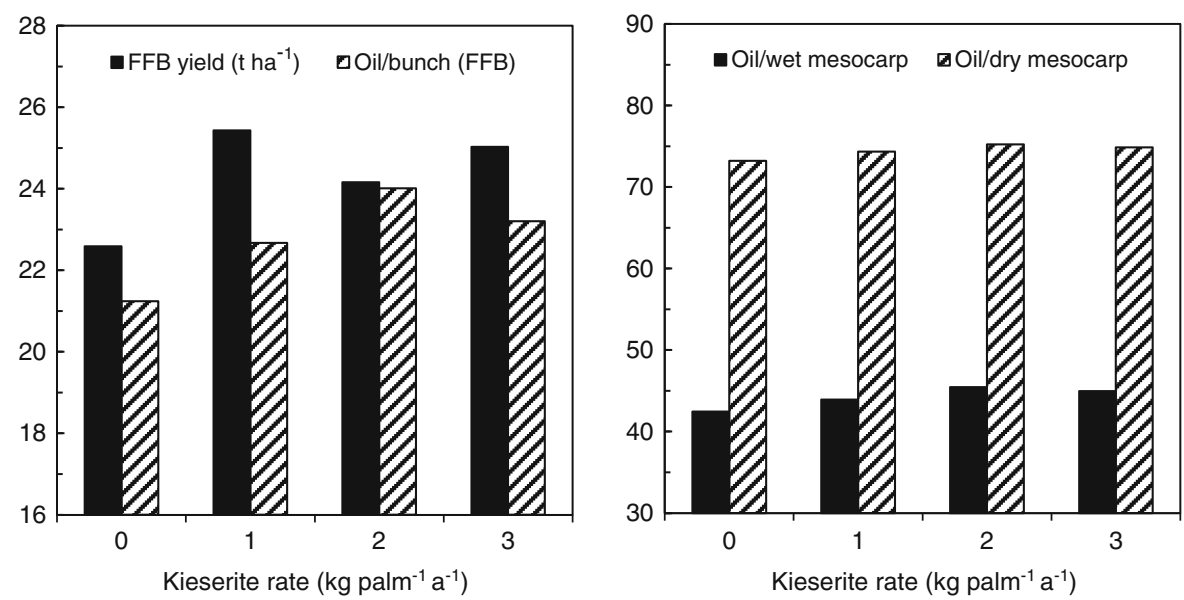
concentration was significantly increased from 39.2 to $40.8 \%$. Nevertheless, as described for oil palm specific quality traits of the oil itself (specific gravity, refractive index, moisture and acid value) did not respond to $\mathrm{Mg}$ application.

Detailed investigations regarding the importance of the soil $\mathrm{Mg}$ status for the $\mathrm{Mg}$ response of rapeseed (Brassica napus L.) were reported by Bogdevich and Mishuk (2006). Magnesium application slightly increased the oil concentration in rapeseed only at low soil $\mathrm{Mg}$ status ( $<150 \mathrm{mg}$ exchangeable $\mathrm{MgO} \mathrm{kg}^{-1}$ soil) indicating that the plants suffered from $\mathrm{Mg}$ deficiency (Fig. 4). On the other hand excessive soil Mg levels (337 mg exchangeable $\mathrm{MgO} \mathrm{kg}{ }^{-1}$ soil) led to a significant reduction of yield. Yield reductions due to such high $\mathrm{Mg}$ contents in the soil are not a consequence of 'Mg toxicity' per se (which has, to our knowledge, not been observed in plants so far), but are due to nutrient imbalances in the soil and consequently the plant. Indeed, such high imbalances in the cation composition may induce deficiencies in other cations like $\mathrm{K}$, and $\mathrm{Ca}$, so that the observed yield reductions are more likely a result of other nutrient's deficiencies. However, on a global scale such conditions are rarely observed.

Soybean (Glycine max (L.) Merr.) Soybean not only represents an important oil crop, but is also grown for its protein. Early studies already reported on the impact of Mg soil application $\left(0-67 \mathrm{kgMgOha}^{-1}\right)$ on yield and quality of soybean (Nelson et al. 1945). They found that increasing the $\mathrm{Mg}$ supply up to $40 \mathrm{kgMgOha}^{-1}$ significantly increased soybean yield, whereas the oil concentration remained almost unchanged. Interestingly, the

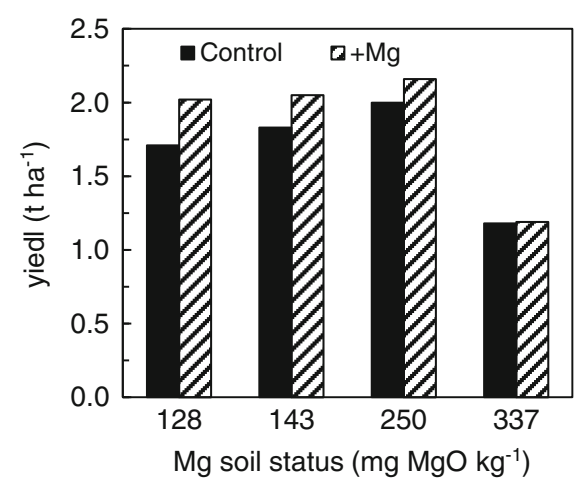

Fig. 4 Influence of $\mathrm{Mg}$ application $\left(8 \mathrm{kgMg} \mathrm{ha}^{-1}\right)$ on seed yield (left) and oil concentration (right) in spring rapeseed as affected by soil $\mathrm{Mg}$ status. The $\mathrm{HSD}_{0.05}$ for seed yield as affected by soil $\mathrm{Mg}$ status and fertilizer treatments were 0.13 and 0.12 , respectively, protein concentration was substantially reduced. The reason for this phenomenon remains unclear as the vital role of $\mathrm{Mg}$ for protein formation and amino acid transport would suggest a positive impact of $\mathrm{Mg}$ supply on protein yield. This assumption is supported by a recent investigation on the effects of irrigation, $\mathrm{P}$ and $\mathrm{Mg}$ supply to soybean grown in southeast Anatolia region demonstrating a significant increase of yield and oil concentration by $\mathrm{Mg}$ application provided the water and $\mathrm{P}$ supply was adequate (Deliboran et al. 2011). In contrast to the study of Nelson et al. (1945) the protein concentration was moderately, but significantly, increased in 1 of 2 years (Fig. 5). Overall, it appears that the protein formation in soybean is moderately affected by $\mathrm{Mg}$ soil application.

In contrast, Vrataric et al. (2006) not only reported a significant increase in seed yield upon a single foliar Mg application of $5 \% \mathrm{MgSO}_{4} \cdot 7 \mathrm{H}_{2} \mathrm{O}$ solution during vegetative growth based on 4-year experiment, but also an increase in the protein and oil concentration. A second foliar application after flowering did not further increase the investigated parameters. The results were in principle agreement with earlier results published by Kovacevic et al. (1991). These results may suggest that in soybean the plant availability of $\mathrm{Mg}$ at later vegetative growth stages, just before flowering, is of particular importance for protein and oil accumulation. It is tempting to speculate that at later growth stage root activity (Mg uptake) is diminishing, so that foliar 'boosting' by $\mathrm{Mg}$ of the leaves delivering the $\mathrm{C}$ - and $\mathrm{N}$-containing compounds to the seeds effectively increases the seed quality. On the other hand too late applications are apparently not effective as the $\mathrm{Mg}$ applied fails to affect assimilate formation and partitioning.

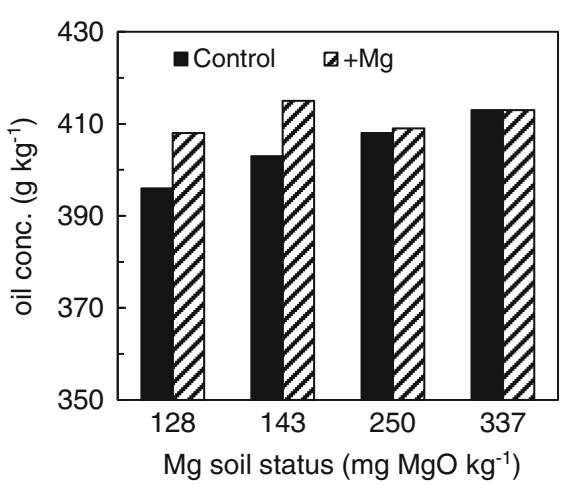

and the $\mathrm{HSD}_{0.05}$ for oil concentration as affected by soil Mg status and fertilizer treatments were 22 and 21, respectively (based on Bogdevich and Mishuk 2006) 


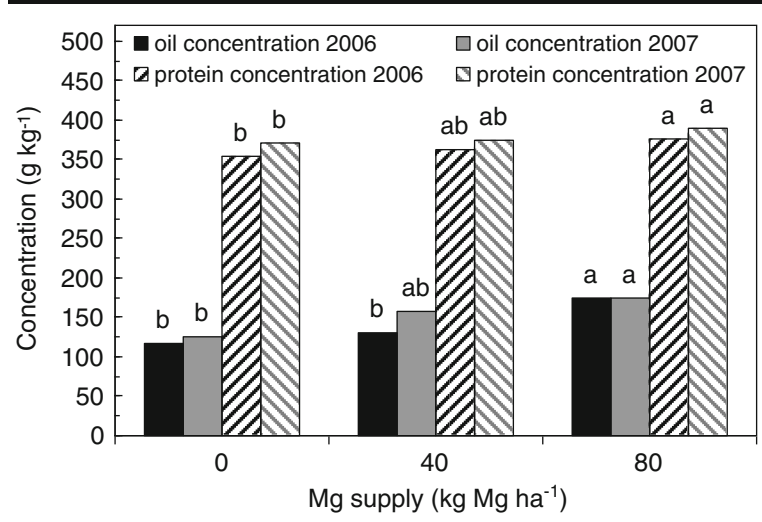

Fig. 5 Influence of $\mathrm{Mg}$ supply on oil and protein concentration of soybean seeds at highest $\mathrm{P}$ and irrigation level (means followed by the same letter are not significantly different; $\mathrm{LSD}_{0.05}$ was $34.95 \mathrm{~g} \mathrm{~kg}^{-1}$ and $19.23 \mathrm{~g} \mathrm{~kg}^{-1}$ in 2006 , and $35.77 \mathrm{~g} \mathrm{~kg}^{-1}$ and $18.64 \mathrm{~g} \mathrm{~kg}^{-1}$ in 2007 for the oil and protein concentration, respectively; based on Deliboran et al. 2011)

\section{Other oil crops}

In groundnut (Arachis hypogaea L.) the significance of $\mathrm{Mg}$ nutrition received limited attention. In a field experiment carried out in India on a slightly alkaline sandy loam for two seasons application of $\mathrm{MgSO}_{4}$ did neither increase yield nor the oil concentration (Rajan et al. 1984).

In sunflower (Helianthus annuus L.) field experiments carried out in India only showed a significant yield response to $10 \mathrm{~kg} \mathrm{Mgha}^{-1}$, whereas the oil concentration remained unchanged (Ahmedkhan et al. 1990). However, the experiment was carried out at a site of high $\mathrm{Mg}$ availability (172 $\mathrm{mg}$ exchangeable $\mathrm{Mg}$ $\mathrm{kg}^{-1}$ soil), so that a yield response beyond the high $\mathrm{Mg}$ availability to the plants might not be expected. In agreement, increasing $\mathrm{Mg}$ application $(0-30 \mathrm{kgMg}$ $\mathrm{ha}^{-1}$ ) on a typic chromusterts soil developed from basalt rock in India containing $56 \mathrm{mmolMg} \mathrm{kg}^{-1}$ also did not affect seed yield, but in tendency increased the seed oil concentration (Sagare et al. 1990). When sunflower was grown on acidic and Mg-deficient soils liming $\left(\mathrm{CaCO}_{3}\right)$ and application of $\mathrm{MgSO}_{4}$ almost doubled achene and oil yield (Csengeri and Kozak 1985a, b). Such treatments also markedly increased the oil concentration in the achenes. Taken together the results show that depending on the soil $\mathrm{Mg}$ availability Mg application can increase yield and oil contents at Mg-deficient sites, indicating that further increases beyond yield optimum do not have an effect. See below for a more elaborate discussion of this point.
Pulses

Azizi et al. (2011) evaluated the effect of different modes of $\mathrm{MgSO}_{4}$ application (soil, foliar and seed treatment, and their combinations) on yield and quality of two lentil (Lens culinaris L.) genotypes in Iran. Highest grain and biological yield were obtained from soil fertilization, whereas the highest percentage of crude protein concentrations in the seeds was obtained from foliar application, which generally agrees with findings in soybean (see above). The same was observed for other parameters like 1,000-seed weight and pod number per plant. There was a significant positive correlation between concentrations of crude protein and $\mathrm{Mg}$ in the seeds. The authors recommend soil plus foliar application of $\mathrm{Mg}$ in order to achieve highest magnesium and crude protein concentrations, which principally agrees with observations in cereals (Grzebisz 2013). As already proposed for soybean, foliar application appears to be effective with respect to increasing the grain protein concentration and in this case also Mg. However, whether the seed $\mathrm{Mg}$ is directly related to protein formation in the seeds or whether this is a consequence of enhanced translocation of amino acids from source leaves to the physiological sinks remains to be elucidated.

Fruits, vegetables and ornamentals

Compared to agricultural crops the various quality parameters of horticultural crops as listed in the introductory section play an extraordinary important role particularly for fresh market produce. Consequently, most investigations on the impact of nutrient supply on quality aspects, particularly organoleptic/sensory properties, are referring to fresh market produce of horticultural crops. As shortly mentioned in the introductory section, purchasing decisions for horticultural produce are often governed by psychological factors (e.g. convenience, price, ease of use, novelty, ethical considerations). However, in developed countries other quality aspects like food safety and the nutritional value and healthiness also affect the final purchasing decisions of consumers.

\section{Fruits}

Pome fruits Mineral nutrients differentially affect internal and external quality parameters of pome fruits like apple (Malus domestica Borkh.). The optimal fruit nutrient concentration required for obtaining an 
envisaged quality characteristic depends on various aspects including the genetic background, the environmental conditions, and the cultivation technique (e.g. fertilization practice). Marcelle (1995) provided an evaluation of favourable 'concentration ranges' of the macronutrients $\mathrm{N}, \mathrm{P}, \mathrm{K}, \mathrm{Ca}$, and $\mathrm{Mg}$ giving an idea about the complexity of the impact of mineral nutrient status on the various apple quality parameters. However, for $\mathrm{Mg}$ it was stated that an impact on 'good eating quality' is not well known except a negative impact on fruit firmness. Accordingly an optimal $\mathrm{Mg}$ concentration 'has to be relatively low' for good storage properties. The physiological background underlying this recommendation are discussed in a review by Bramlage et al. (1980) arguing that the commonly described effects of various nutrients including $\mathrm{N}, \mathrm{P}$, $\mathrm{K}, \mathrm{Mg}$, and $\mathrm{B}$ on the quality of pome fruits are to certain extent a consequence of their interaction with $\mathrm{Ca}$. The authors distinguished between the impact of $\mathrm{Mg}$ on fruits and the vegetative part of the plants harbouring the fruits. They stated that there is only very little evidence that $M g$ deficiency or $M g$ excess directly affects fruit quality, even though the fruit trees suffering from $\mathrm{Mg}$ deficiency appear weak and unproductive. This view was underlined by Marcelle (1995) who suggested that most of the effects of $\mathrm{Mg}$ on fruit quality can be explained (1) by antagonism between $\mathrm{Mg}$ and $\mathrm{K}$ and (2) by competition of $\mathrm{Mg}$ and $\mathrm{Ca}$ 'for fixation sites during transport'. A proof of the statements given by Bramlage et al. (1980) and Marcelle (1995) is the well-known and often occurring bitter pit disorder in apple. Bitter pit, in addition of giving an undesirable appearance, reduces texture and taste of apple fruits. Bitter pit is a consequence of insufficient $\mathrm{Ca}$ supply to the fruits. Even though $\mathrm{Mg}$ itself is not directly related to this nutritional disorder, the $\mathrm{Ca} / \mathrm{Mg}$ ratio can serve as an indicator for the incidence of bitter pit (Askew et al. 1960). However, Marcelle (1995) states that in older literature the evaluation of the susceptibility to bitter pit was determined by forming two different ratios including $\mathrm{Mg}: \mathrm{K} /(\mathrm{Ca}+\mathrm{Mg})$ and $(\mathrm{K}+\mathrm{Mg}) / \mathrm{Ca}$. The first ratio puts emphasis on the transport antagonism between monovalent and divalent cations, whereas the latter ratio points to the specific antagonistic effect of $\mathrm{K}$ and $\mathrm{Mg}$ in $\mathrm{Ca}$ accumulation. Based on the observation that bitter pit development was more closely related to $(\mathrm{K}+\mathrm{Mg})$ / $\mathrm{Ca}$ ratio than the $\mathrm{K} / \mathrm{Ca}, \mathrm{Mg} / \mathrm{Ca}, \mathrm{K} / \mathrm{Mg}$ ratios alone and the fact that the correlation was only slightly better for
$(\mathrm{K}+\mathrm{Mg}) / \mathrm{Ca}$ than for $\mathrm{K} / \mathrm{Ca}$ (Garman and Mathis 1956), Bramlage et al. (1980) suggest that Mg may play only a minor role in bitter pit development compared to K. More recently Burmeister and Dilley (1991, 1993) developed an artificial system for studying bitter pit development in apple. The authors induced bitter pit in harvested apple fruits by infiltration with $\mathrm{Mg}$-containing solutions. This procedure was capable of simulating naturally occurring bitter pit disorder by changing the fruit internal $\mathrm{Ca} / \mathrm{Mg}$ ratio (Burmeister and Dilley 1991).

The competition of the main base cations $\mathrm{K}, \mathrm{Ca}$ and $\mathrm{Mg}$ was also discussed as causal factor responsible for the negative impact of high fruit $\mathrm{Mg}$ content on fruit firmness, an important storage quality parameter, in a review by Marcelle (1995). In contrast, a 5 -year soil fertilization experiment conducted by Noè et al. (1995) comparing different $\mathrm{N}, \mathrm{K}$ and $\mathrm{Mg}$ treatments on 'Golden Delicious' apples showed that $\mathrm{Mg}$ fertilization improved fruit firmness. However, the results presented in that study were quite variable. Also, even though the authors stated that $\mathrm{Mg}$ deficiency is frequently observed in the experimental area the soil $\mathrm{Mg}$ contents even exceeded the soil K contents. Therefore, a beneficial effect of $\mathrm{Mg}$ fertilization may not be expected. Instead, the observed increasing firmness by Mg application may be a secondary effect not directly related to $\mathrm{Mg}$. This is underlined by the fact that the fertilization treatments affected neither fruit $\mathrm{Mg}$ nor fruit $\mathrm{Ca}$ concentration and only slightly increased the $\mathrm{K}$ concentration.

Consumer acceptance of horticultural produce strongly depends on fruit appearance, for which - with respect to pome fruits - the skin colour is most significant. Reay et al. (1998) investigated the effect of foliar urea and $\mathrm{MgSO}_{4}$ sprays on chlorophyll, carotenoid and anthocyanin concentrations in apple skin. All three constituents are not only thought to be health promoting agents but also play decisive roles in apple skin colouration. The $\mathrm{Mg}$ treatment of the tree canopy increased the chlorophyll and carotenoid concentration on the back side of the fruit (not facing the sun). Concerning a consumer-oriented approach to quality one should remember that the chlorophyll and carotenoid concentrations determine the 'backcolour' of the fruit ranging from light green to pale yellow. When using this colour for grading food maturity in exportoriented regions like New Zealand a greener colour means that less fruits are suitable for export at a given harvest date or the fruits need more time to reach the 
desired maturation state (Reay et al. 1998). The 'greening effect' of Mg supply may be associated with increased chlorophyll formation or, more likely, decreased/delayed chlorophyll degradation. Enhanced assimilate translocation might also be involved in mediating this effect at physiological level. A deeper understanding of the impact of $\mathrm{Mg}$ on the ripening processes in pome fruits is required to design targetoriented fertilization strategies. Also, the response to $\mathrm{Mg}$ supply in terms of ripening and colour formation and development may be cultivar-specific.

Taste and flavour related characteristics of pome fruits are dependant on the ripening stage as is the storage quality. A number of indices incorporating some of the important traits determining taste, flavour and storage characteristics in apple like titratable acidity (TA), (total) soluble solid (TSS) concentrations, fruit firmness and starch degradation have been developed, namely the Streif (Kaack and Pedersen 2011), and the Perlim and the Thiault index (e.g. Rabiei et al. 2011). These are used for determining the ripening stage, the ideal harvest period and changes upon storage and are to a great extent cultivar-specific. According to the role of $\mathrm{Mg}$ in balancing ion charges and $\mathrm{pH}$ and in the formation and translocation of metabolites an impact of $\mathrm{Mg}$ on each of these quality parameters is to be expected. Particularly the Thiault index (total sugar $\left(\mathrm{g} \mathrm{L}^{-1}\right)+10 \times$ acidity $(\mathrm{g} / \mathrm{L})$, with total sugar $=$ $($ Brix $\times 10.6-20.6)$ can readily be modulated by fertilization. Even though the consumer preferences for taste and flavour might differ between regions/ countries, a high index is typically regarded as a positive flavour and, therefore, quality trait. Hence, the negative relationship between the $\mathrm{Mg}$ concentration of the fruit and the Thiault index thus indicates a negative effect of $\mathrm{Mg}$ on apple quality (Marcelle 1995). However, the author explicitly state that this is not a direct consequence of high $\mathrm{Mg}$ but of an imbalanced cation (e.g. Ca and K) supply to the fruits underlining the initially described importance of the cation ratios rather than the $\mathrm{Mg}$ concentration alone. In 2 years (1994-1995) and seven different apple orchards growing six different apple cultivars Dris et al. (1999) investigated the relationship between the nutrient (e.g. N, P, K, Ca, and $\mathrm{Mg}$ ) concentration of leaves from fruit-bearing branches $(\mathrm{BF})$ and nonbearing branches (BNF) and the apple quality parameters including nutrient concentrations, fruit diameter, juice $\mathrm{pH}$, TA, and TSS concentration. Even though there was quite a close relationship between the $\mathrm{Mg}$ concentrations in leaves of $\mathrm{BF}$ and BNF and fruits, none of the investigated quality parameters was correlated with the leaf $\mathrm{Mg}$ concentration. However, the $\mathrm{Mg}$ concentrations may not have reached severe deficiency levels (never $\leq 0.125 \mathrm{mg} \mathrm{Mg} \mathrm{g}^{-1}$ d.m.). Apparently, in this study the investigated quality traits remained stable within a certain leaf tissue $\mathrm{Mg}$ concentration range. It may be concluded that $\mathrm{Mg}$ levels in a more severe deficiency range would have imposed quality changes as a consequence of disturbed metabolism. Also it can be speculated that Mg supply/concentrations beyond optimum would have negatively affected these quality traits as a consequence of imbalanced cation ratios (as described in the previous paragraph). However, in a 5 -year study conducted by Noè et al. (1995) apples from Mg-treated trees (soil fertilization) showed higher TSS and acid concentrations as compared to $\mathrm{N}$ and $\mathrm{K}$ treatments after storage, whereas after harvest the TSS was lower. In this study the Mg concentration in the leaves did not fell below $0.25 \mathrm{mg}$ $\mathrm{Mg} \mathrm{g}^{-1}$ d.m. In conclusion, it appears that flavour determining ingredients in the selected studies were not or marginally affected by $\mathrm{Mg}$ nutrition verifying the statement given by Bramlage et al. (1980) that $\mathrm{Mg}$ deficiency or excess have hardly any effect on apple quality. Even though there are numerous other studies available investigating the effects of mineral nutrition including $\mathrm{Mg}$ on apple fruit quality, the selected references were selected as appropriate examples.

Stone fruits As described for pome fruits $\mathrm{Mg}$ was often co-investigated with other mineral nutrients, particularly $\mathrm{Ca}$ as the nutrient having the greatest impact at least on fruit appearance and texture. The few results reported considering $\mathrm{Mg}$ mostly dealt with quality traits related to storability.

Serrano et al. (2004) conducted a trial with peach (Prunus persica (L.) Batsch) and nectarine (Prunus persica (L.) Batsch var. nucipersica (Suckow) C.K. Schneid.) trees, which were sprayed at three different growth stages (after harvest in the previous year, 10 days after anthesis at the beginning of April, and right before manual thinning at the end of April) with a formulation containing $\mathrm{Ca}, \mathrm{Mg}$ and $\mathrm{Ti}$ (evaluation per ion was not done) to investigate quality parameters (1) at harvest, (2) after 7-28 days of cold storage and (3) after subsequent ripening for 4 days at $20{ }^{\circ} \mathrm{C}$. Fruits of treated plants exhibited higher weight and pulp firmness than control 
fruits, whereas no effect was observed on colour, TSS content, TA or the time required for ripening on the tree. Lower levels of weight loss, colour evolution, TSS/TA ratio and ethylene production but higher pulp firmness were found in treated peaches and nectarines compared to control fruits during the cold storage phase. In addition, the storability of treated fruits could be prolonged by up to 14 days compared to fruits from control plants as a consequence of improved parameters related to ripening. However, in view of the co-application of $\mathrm{Mg}$ with $\mathrm{Ca}$ and $\mathrm{Ti}$ and the small effects of $\mathrm{Mg}$ on the investigated traits in other crops, the improvement of the fruits appears to be predominantly a consequence of $\mathrm{Ca}$ and Ti supply. The same conclusion can be drawn from a 1-year study of Alcaraz-López et al. (2004). The authors used sprays containing $\mathrm{Ca}, \mathrm{Mg}$ or $\mathrm{Ti}$ on peach trees with special emphasis on improving mechanical properties of the fruits. Again the experimental design does not allow any conclusion on a single $\mathrm{Mg}$ effect, but the combined treatments increased tree performance (branch elongation, flowering and fruit set intensities) and fruit size, improved resistance of the fruits to compression and penetration, and decreases weight loss during postharvest storage. The authors concluded that treatments seemed to delay the apparent ripening status. The same working group observed somewhat positive effects of foliar Mg spray on flesh firmness (AlcarazLopez et al. 2003). Again, a combined treatment with Ti significantly increased peel and flesh firmness, fruit size and weight, compression and impact resistance, the ripening index and to some extent fruit colour. Table 2 provides an impression on the inter-experimental variation of the results.

Grape/grapevine (Vitis vinifera L.) Production of quality grapes suitable for wine-making depends on numerous factors. Moretti (2002) stated that among intrinsic (degree of wood maturation, content of nutritive and nitrogenous compounds) and external factors (temperature, rain distribution, soil parameters) the quality of wine produced is also modulated by fertilization to a certain degree. The author reduced this effect mainly to fertilization-induced improved root and shoot growth and the subsequent impact on vine performance. Even though this statement is rather vague, Moretti (2002) in a 3-year trial found that foliar application of $\mathrm{Mg}$ (and $\mathrm{Zn}$ ) enhanced shoot length and lignification and increased root number thereby laying the cornerstone for high quality production. A more direct relationship between $\mathrm{Mg}$ supply and yield and grape quality was presented by Stefanini et al. (1994) based on trials conducted near Paolo del Colle. Two cultivars (Trebbiano toscan, Uva di Troia) received $\mathrm{MgSO}_{4}$ as foliar fertilizer (at low rates), via fertigation or applied to the soil at rates of ca. 36 and $72 \mathrm{kgMg}$ $\mathrm{ha}^{-1}$. They observed that $\mathrm{Mg}$ increased the weight of prunings in Uva di Troia irrespective of the application method. In contrast Trebbiano toscano did not respond (fertigation, soil application) or even reduced weight of prunings after foliar $\mathrm{Mg}$ application. Also, the $\mathrm{Mg}$ treatment reduced the fruit yield of cultivar Trebbiano toscano, whereas $\mathrm{Mg}$ application via fertigation increased fruit yield in Uva di Troia. The results further underline the initial statement that grape yield and quality parameters are subject to various intrinsic and experimental factors. Obviously, cultivar-intrinsic factors are also responsible for the differences of the cultivars in the response to $\mathrm{Mg}$ application.

There are several mineral nutrition-related disorders in grape production, e.g. Fe deficiency chlorosis or stem necrosis. Even though not yet fully understood, it is thought that the $\mathrm{Ca}$ and $\mathrm{Mg}$ nutrition plays a key role in the development or avoidance of stem necrosis, a disorder periodically occurring in important grape varieties (Rupp et al. 2002). Foliar spraying with $\mathrm{Mg}$ containing fertilizers is a common practice to correct nutrient imbalances in grape to reduce the risk of stem necrosis. On the other hand it is felt that late applications of agrochemicals including fertilisers may negatively affect wine processing and quality, and this concern is particularly strong for a compound known as 'bitter salt'. By conducting field trials over 3 years Rupp et al. (2002) showed that foliar sprays with $\mathrm{MgSO}_{4}$ or $\mathrm{MgO}$ during the functional period of veraison (onset of ripening) increased the $\mathrm{Mg}$ content of grapes and must, but organoleptic testing of the resulting vines did not reveal any impact of foliar $\mathrm{Mg}$ fertilization on wine taste. The authors concluded that late $\mathrm{Mg}$ application is safe regarding wine quality.

Red grape varieties are distinguished by their anthocyanin content that are plant polyphenolic constituents exhibiting antioxidative activities (Miguel 2011). It was demonstrated that the degradation of anthocyanins is reduced due to $\mathrm{Mg}$ supply (Shaked-Sachray et al. 2002), and more recently the same group provided evidence that $\mathrm{Mg}$ appears not to increase the biosynthesis, but rather to decrease the catabolism of anthocyanins in grape using cell suspension cultures (Sinilal et al. 


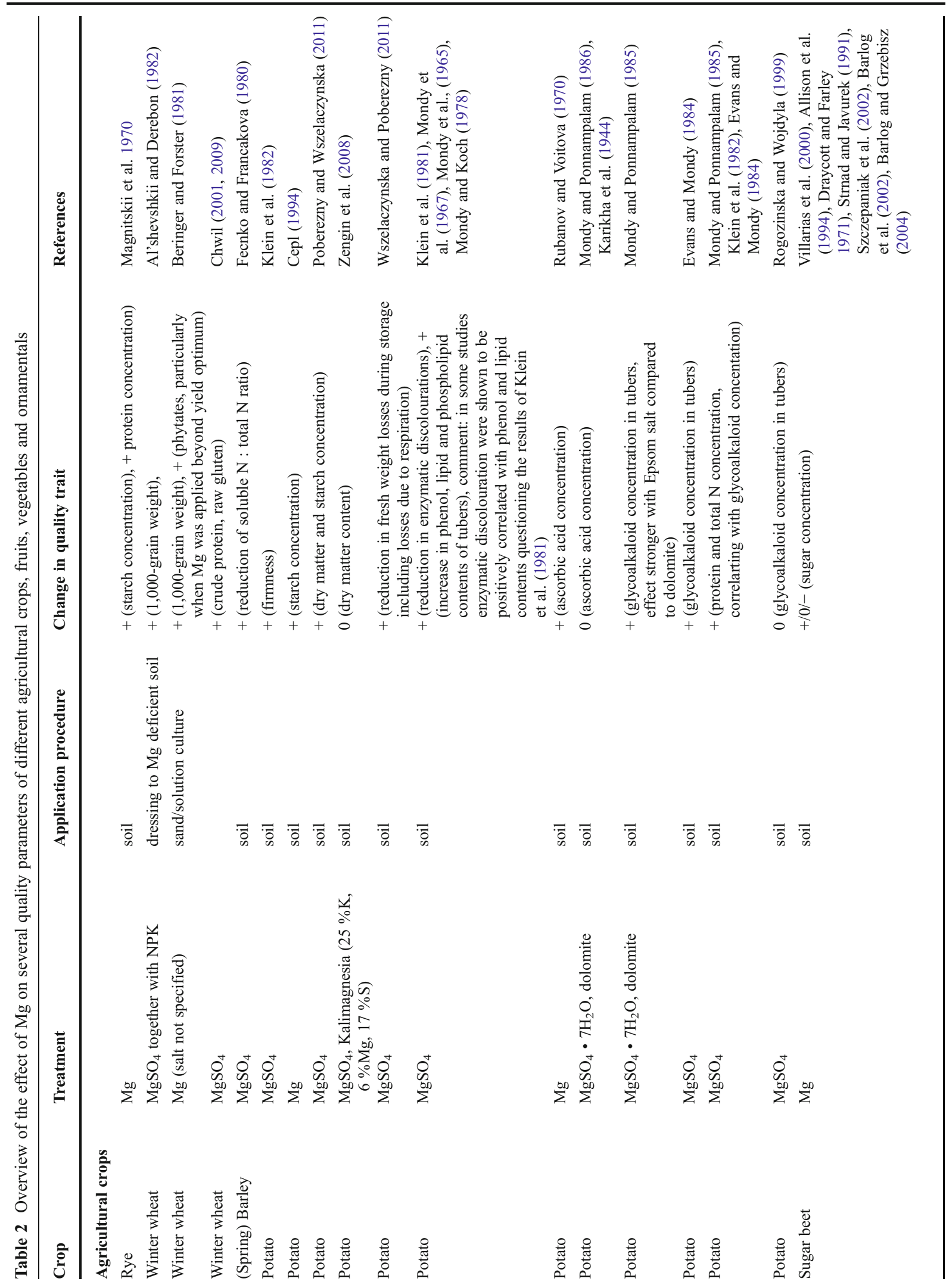




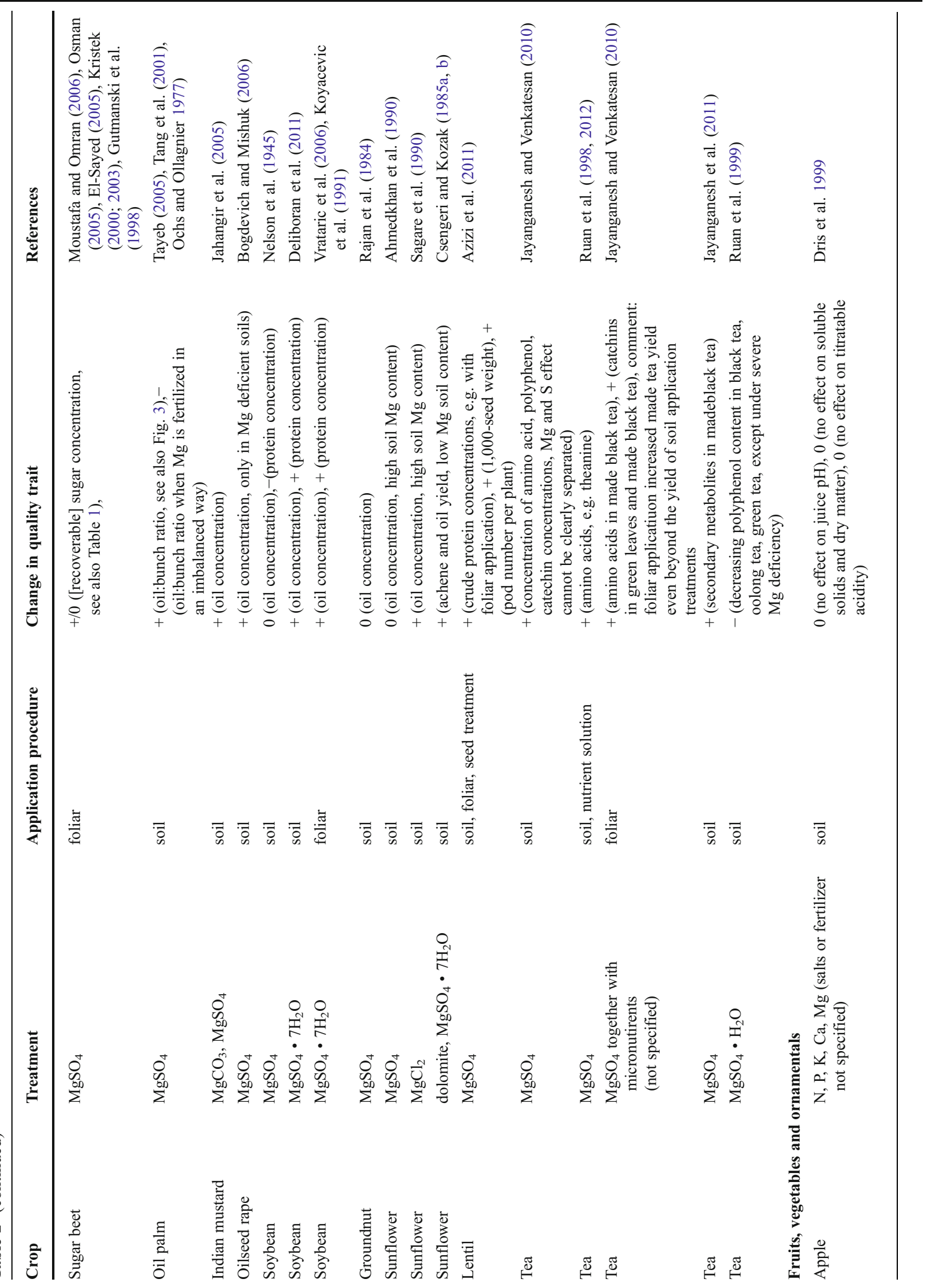




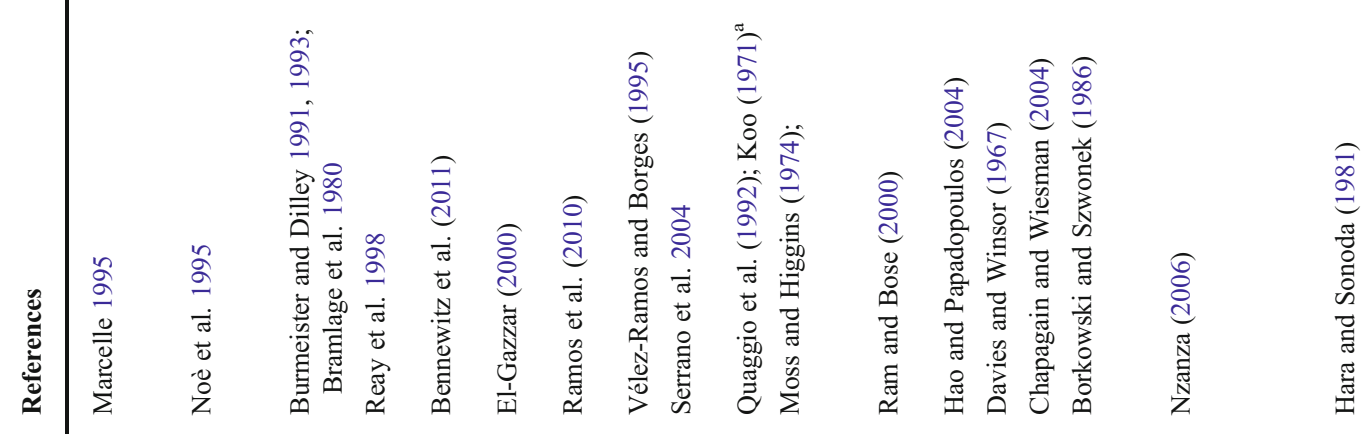

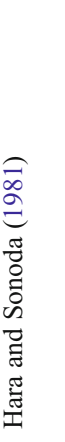

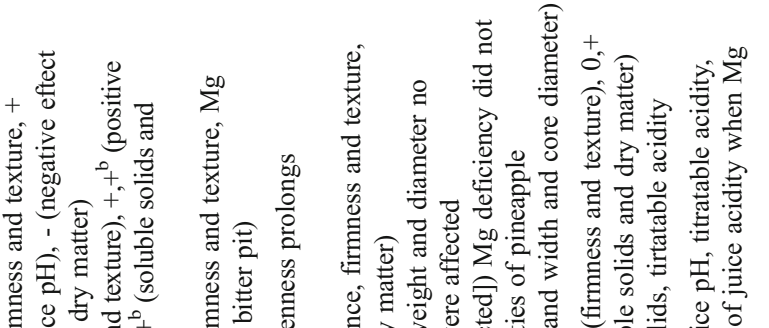


2011). It would be interesting whether this phenomenon also occurs in important other crops and how this phenomenon operates at the molecular level.

\section{Tropical fruits/exotic fruits}

Citrus fruits (Citrus sp.) Morton et al. (2008) stated that an effect of $\mathrm{Mg}$ fertilization on citrus quality parameters is only likely under severe $\mathrm{Mg}$ deficiency conditions. Of course, severe Mg deficiency deeply disrupts plants metabolism which will certainly affect quality and yield as well. Magnesium deficiency is a typical problem of acidic soils, which are often $\mathrm{Mg}$ deficient (Gransee and Führs 2013, this issue). Overlaying the main citrus production sites with the distribution of acidic soils worldwide shows an increased risk of $\mathrm{Mg}$ deficiency in citrus production in many parts of the world. Indeed, Quaggio et al. (1992) investigating the effect of liming of acidic and $\mathrm{Mg}$ deficient Brazilian soils planted with citrus trees with dolomitic limestone found that the TSS and acid concentrations in fruits linearly increased with dolomitic limestone application for seven years. These increases were strongly correlated with the leaf $\mathrm{Mg}$ concentrations and already observed by Koo (1971). Moss and Higgins (1974) conducted a sand experiment under greenhouse conditions for one season. They concluded that particularly the increase in fruit acids (occurring at high $\mathrm{Mg}$ treatment) might be related to an increased $\mathrm{Ca} / \mathrm{Mg}$ rather than an increased $\mathrm{K} / \mathrm{Mg}$ ratio as previously suggested. This might explain the high acid concentration, as an additional uptake of $\mathrm{Mg}$ at almost unchanged potassium uptake might have led to increased organic acid production to counterbalance the increased cellular cation accumulation. Fruit acidity can be a critical factor as too high acidity, or low brix:acid ratio, delays maturation, particularly when Mg-accumulating rootstocks are planted (Moss and Higgins 1974). In another 2-year study Ram and Bose (2000) found that despite the high nutrient demand of mandarin orange effects of foliar $\mathrm{Mg}$ and micronutrient $(\mathrm{Cu}, \mathrm{Zn}, \mathrm{Fe}, \mathrm{B})$ application on TSS, total sugar, reducing sugars and fruit acidity were not significant, even though the fruit yield was indeed higher (except when copper was applied together with the other nutrients). Table 2 summarises the variation in results of different investigations. At present it is uncertain to what extent this variation is a consequence of the different cultivars and soils/locations used. 
Pineapple (Ananas comosus (L.) Merr.) Pineapple represents an important and popular tropical fruit crop, but studies on the impact of $\mathrm{Mg}$ on its quality are limited. Based on omission experiments carried out in Brazil for 3 years Ramos et al. (2010) concluded that Mg deficiency does not alter the sensory properties (acidity, total soluble solids, vitamin C, pulp colour) of the pineapple fruit (cultivar 'Imperial'). Yield data indicating a growth limitation due to insufficient $\mathrm{Mg}$ supply where not reported pointing to a mild $\mathrm{Mg}$ deficiency level. This may explain the absence of effects on sensory properties as the deficiency level was not yet sufficient to markedly affect metabolic processes.

In pineapple nutrients are often applied as foliar spray. In a 1-year trial Velez-Ramos and Borges (1995) could indeed demonstrate a positive effect of $\mathrm{Mg}$ on pineapple yield as the average length and width of the fruit and the core diameter increased significantly with increasing $\mathrm{Mg}$ applications at high $\mathrm{K}$ and $\mathrm{N}$ supply levels (cultivar 'Red Spanish'). In general, in the planted crop a higher fruit acidity was associated with higher doses of $\mathrm{K}$ and $\mathrm{Mg}$, which agrees with previous findings in this crop (Py et al. 1987) and with considerations given in the previous section on Citrus. However, a significant effect of $\mathrm{Mg}$ foliar application on the quality of the ratoon crop could not be demonstrated. Hence, for this fruit crop, too, it appears that comprehensive studies are needed to clarify the role of $\mathrm{Mg}$ in the formation of the different quality traits under various agroecological conditions and options for $\mathrm{Mg}$ administration.

\section{Vegetables}

As mentioned in the previous section already, in vegetables the ratios of the cations $\mathrm{Mg}, \mathrm{K}$, and $\mathrm{Ca}$ often are more closely correlated to the quality trait than the concentration or supply of the nutrient under consideration.

Tomato (Solanum lycopersicum L.) How does $\mathrm{Mg}$ supply affect fruit appearance, texture and nutrient-dependent fruit disorders affecting the quality of tomatoes? A summary of the results of different experiments is given in Table 2. For 1 year, Hao and Papadopoulos (2003) investigated the effect of differentiated $\mathrm{Ca}$ and $\mathrm{Mg}$ supply on the physiological disorders blossom end rot (BER) and russeting, and on fruit firmness when grown in rockwool. As expected at very narrow $\mathrm{Ca} / \mathrm{Mg}$ ratios BER was enhanced. Increasing the $\mathrm{Ca} / \mathrm{Mg}$ ratio reduced BER incidence. Unexpectedly, high $\mathrm{Mg}$ supply together with low Ca supply increased fruit firmness, whereas this effect of $\mathrm{Mg}$ was observed under high $\mathrm{Ca}$ supply only at later growth stages. Fruit russeting was lowest when $\mathrm{Ca}$ and $\mathrm{Mg}$ were supplied in a ratio not lower than 6:1. A study published later by the same group showed that at a given $\mathrm{Ca}$ supply increasing the $\mathrm{Mg}$ application enhanced the biomass allocation to the fruit, whereas the allocation to the leaves decreased, pointing to the decisive role of $\mathrm{Mg}$ in carbohydrate partitioning (Hao and Papadopoulos 2004). As a consequence of another cation interaction in soil-grown processing tomatoes Hartz et al. (1999) found that K-nutritional disorders like yellow shoulder and internal white tissue in processing tomatoes was more closely correlated with the soil exchangeable $\mathrm{K} / \sqrt{ } \mathrm{Mg}$ than with soil $\mathrm{K}$ availability. In a non-repeated experiment Borkowski and Szwonek (1986) supplied tomato plants grown in peat with varying $\mathrm{K}(200-1,000 \mathrm{mgK}$ $\mathrm{1}^{-1}$ substrate) and $\mathrm{Mg}\left(50-200 \mathrm{mgl}^{-1}\right)$ combinations. The highest marketable, high quality yield was observed when $\mathrm{K}$ and $\mathrm{Mg}$ were supplied in the highest amounts at a ratio of $5: 1$. This clearly points to the fact that only balanced crop nutrition can result in optimal quality.

With respect to fresh market tomatoes consumer acceptance is mainly determined by flavour e.g. by sweetness and sourness (Stevens et al. 1979; Malundo et al. 1995). An important measure for sweetness and sourness are sugars (TSS) and TA, respectively. Magnesium acts as (mobile) cation in metabolite formation and translocation to fruits (Römheld and Kirkby 2007, see previous sections), and a quality-determining effect of $\mathrm{Mg}$ on the flavour characteristics of fresh market tomatoes might therefore be expected. Even though hardly any study investigated the effect of $\mathrm{Mg}$ nutrition on tomato quality specifically some information can be extracted from studies investigating the effect of combined $\mathrm{Mg}, \mathrm{Ca}, \mathrm{K}$, and $\mathrm{N}$ nutrition. However, these studies provide quite an inconsistent picture on the effect of $\mathrm{Mg}$ on tomato quality. Using fruits from a long-term field trial varying $\mathrm{N}$, $\mathrm{K}, \mathrm{P}, \mathrm{Ca}$, and $\mathrm{Mg}$ supply Davies and Winsor (1967) did not observe an effect of $\mathrm{Mg}$ 
fertilization on tomato fruit composition, while effects of $\mathrm{K}$ (close relationship between $\mathrm{K}$ concentrations and acidity of fruit juices) and, to a lesser extent, $\mathrm{N}$ supply could be demonstrated. In a greenhouse experiment conducted for 1 year using a randomized block design with four replications Chapagain and Wiesman (2004) investigated the partial replacement of $\mathrm{KCl}$ in a fertigation solution by $\mathrm{KCl}+\mathrm{MgCl}_{2}$. Use of the combined $\mathrm{K}$ and $\mathrm{Mg}$ treatment improved the quality of the fruit by increasing its glucose, dry matter and $\mathrm{Mg}$ contents. The authors concluded that $\mathrm{KCl}$ treatment improved fruit appearance and quality, which was even further enhanced by $\mathrm{MgCl}_{2}$ treatments. However, they also state the need for more investigations on the interaction of $\mathrm{Mg}$ in greenhouse tomato fertigation. Hao and Papadopoulos (2004) investigated the effect of differentiated $\mathrm{Ca}$ and $\mathrm{Mg}$ supply to tomato on various fruit quality parameters including dry matter and TSS when grown on rockwool. Neither the TSS nor the dry matter content were considerably affected by $\mathrm{Mg}$ supply except that under high $\mathrm{Ca} / \mathrm{Mg}$ ratio both parameters were reduced.

The inconsistency of the results reported stress the need for additional investigations to improve our understanding of the importance of $\mathrm{Mg}$ nutrition on metabolite translocation and fruit quality considering the various growing conditions, productions systems and usage relevant in commercial tomato production.

Cabbages (Brassica oleracea L. sp.) Effects of $\mathrm{Mg}$ supply on cabbage quality have been described only to limited extent. In the case of cabbage the definition of quality is extended to head weight and size as quality determining traits. In a non-repeated study investigating the contribution of $\mathrm{Mg}$ (and $\mathrm{Ca}$ and $\mathrm{S}$ ) on cabbage ( $B$. oleracea var. capitata L.) head-formation Hara and Sonoda 1981 found an optimum relationship for $\mathrm{Mg}$ in the outer leaves and cabbage head yield (determined by head weight and size). In this study $\mathrm{Mg}$ concentrations in the dry matter below $0.15 \%$ (Mg deficiency) or above $1.5 \%$ (cation antagonism with $\mathrm{Ca}$ and $\mathrm{K}$ ) reduced head yield. However, as this study was not repeated final conclusions are difficult to derive. Another study investigated the effect of $\mathrm{MgSO}_{4}$, amino-acid chelated $\mathrm{Mg}$ (Mg-AA), and Mg-EDTA on quality parameters of Chinese cabbage (Brassica rapa L., ssp. pekinensis, Han et al. 2010). As concentrations of chlorophyll, soluble sugar, soluble protein and vitamin $\mathrm{C}$ were increased only by $\mathrm{Mg}$-AA, whereas the other $\mathrm{Mg}$ sources increased yield only, it is concluded that the improvement of quality due to Mg-AA supply in Chinese cabbage appears to be more related to the additional amino acid rather than to genuine $\mathrm{Mg}$ effects.

Flowering Chinese cabbage (Brassica campestris L. ssp. chinensis var. utilis Tsen et Lee) and Pak Choi (Brassica rapa L., ssp. chinensis, Bai Cai) are important vegetables in China, Korea and Japan, and contribute valuable amounts of ascorbic acid (vitamin C) to the local diet. Liu et al. (2008) reported that $\mathrm{Mg}$ deficiency reduced the vitamin $\mathrm{C}$ and soluble protein concentration in the stalk of flowering Chinese cabbage indicating the importance of a sufficient $\mathrm{Mg}$ supply for optimal healthiness of the product.

Not only in view of the importance of cabbage in the human diet, additional studies are needed to clarify the effects of $\mathrm{Mg}$ supply on cabbage quality.

Tea (Camellia sinensis (L.) Kuntze) In the context of this review the term 'tea' refers to fermented (black), semi-fermented (oolong) and non-fermented (green) Camellia teas (Ruan et al. 1999), and the focus of attention is put on the economically most important black and green teas. The quality of made tea-the final product of processing-largely depends on the chemical composition of the raw material used-the harvested tea leaves - and their required quality characteristics largely depend on the intended type of tea being produced.

The two most important chemical groups with respect to the liquor characteristics of a black tea infusion are theaflavins and thearubigins formed during the fermentation process (more precisely an enzymatic oxidation) from polyphenolic precursors and therefore the quantitative and qualitative composition of polyphenols (catechins) is most important for black tea processing (Ruan et al. 1999; Kumar et al. 2011). In addition, numerous volatile compounds primarily formed during processing from precursors like primary (fatty acids Okal et al. 2012, amino acids and proteins, Kottur et al. 2010) and secondary metabolites, are also important quality traits when producing black tea.

On the other hand for green tea, the concentration of catechins, known for their adstringency, in harvested leaves should be moderately high as 
biochemical reactions are kept to a minimum during green tea manufacture (Ruan et al. 1999). In green tea the adstringent and bitter catechins are balanced by high concentrations of free amino acids (typically $1-$ $5 \%$ d.w.) that not only contribute to the mellowness and freshness of the infusion, but together with soluble sugars also act as precursors of volatile, flavourdetermining constituents (Ruan et al. 2012). Hence, an optimum ratio of polyphenols (catechins) to free amino acid is therefore critical for the production of quality green and oolong tea (Ruan et al. 1999; Ma et al. 2005).

Due to the acidic soil conditions preferred by tea, its commercial production typically occurs on highly withered, Mg-deprived soils (Ruan et al. 2012), and Jayaganesh and Venkatesan (2010) considered $\mathrm{Mg}$ the most important nutrient next to $\mathrm{N}$ and $\mathrm{K}$ in commercial black tea cultivation. Accordingly, based on a perennial trial with black tea Jayanganesh and Venkatesan (2010) reported that soil application of $200-300 \mathrm{~kg} \mathrm{Mg} \mathrm{ha}^{-1}$ in sulphate form to a standard NPK basal dressing increased amino acid, polyphenol concentration and catechin concentrations by about $10-20 \%$ in green leaves and made black tea. Consequently, the so-called made-tea yield was increased by about $4 \%$ as well. This correlated with an increase in foliar $\mathrm{Mg}$ concentrations. However, as $\mathrm{N}$ was applied as urea and $\mathrm{K}$ as $\mathrm{KCl}$ some of the quality and quantity improvements assigned to $\mathrm{Mg}$ application may have been, at least partially, caused by the provision of sulphate. In fact, Ruan et al. (1998) provided evidence by comparing application of $\mathrm{Mg}$ (and $\mathrm{K}$ ) either as oxide (and chloride) or as sulphate to plants grown for green tea production (3-fold replicated experiments) that sulphate-being a component of the cysteine and methionine-plays an important role in the formation of amino acids in leaves of tea plants. In addition the authors found that nitrate reductase activity was enhanced under $\mathrm{K}$ but even more so under combined $\mathrm{K}$ and $\mathrm{Mg}$ supply, indicating that both nutrients play an important role in the assimilation of $\mathrm{N}$ and thus in the formation of $\mathrm{N}$ containing metabolites e.g. amino acids. Nitrogen assimilation, taking place ultimately in the chloroplasts, is a highly energy consuming process (eight mol electrons $\mathrm{mol}^{-1}$ nitrate). In view of the fundamental functions of $\mathrm{Mg}$ in photosynthesis the increased $\mathrm{N}$ assimilation and subsequent accumulation of amino acids after $\mathrm{Mg}$ application indicates that in $\mathrm{Mg}$ omission treatments tea plants suffered from $\mathrm{Mg}$ deficiency. Indeed, the authors stated that the soil used in the experiment showed a poor nutritional status (Ruan et al. 1998). In nutrient solution experiments carried out with green tea it was recently shown that sufficient $\mathrm{Mg}$ supply increased biomass production and concentrations of quality-forming amino acids in tea, e.g. theanine, in young roots and shoots (Ruan et al. 2012, four replications, 1-year experiment). Moreover, from pot and field experiments the authors concluded that adequate $\mathrm{Mg}$ supply led to increased concentrations of amino acids and sugars in vascular saps as a result of increased demand of younger growing tissues for metabolites. It was speculated that this mobilization of carboncontaining compounds was related to seasonspecific increased demands of young, growing tissues. This clearly demonstrates the decisive role of $\mathrm{Mg}$ in the translocation of metabolites (Cakmak et al. 1994) and, therefore, for quality formation in tea.

Whereas a positive impact of $\mathrm{Mg}$ on amino acid production appears to be proven, the impact on the secondary metabolism responsible for the formation of quality- and flavour-determining compounds appears more complex. In the study of Jayanganesh and Venkatesan (2010) the effect of foliar sprays containing $1 \%$ or $2 \% \mathrm{Mg}$ (representing 2 or $4 \mathrm{~kg} \mathrm{Mgha}^{-1}$ ) including micronutrients on black tea quality was investigated. The treatment further increased the leaf $\mathrm{Mg}$ concentrations beyond the level observed for soil application (200$300 \mathrm{~kg} \mathrm{Mgha}^{-1}$ ) without increasing, but even decreasing the quality-determining amino acid concentrations in green leaves, which remained almost at the unfertilized control level. In contrast, the amino acids in made black tea were increased by this foliar application. Moreover, in both green leaves as well as in made black tea, the secondary metabolites polyphenols (catechins) were increased by foliar application. These quality improvements by foliar $\mathrm{Mg}$ and micronutrient application increased the made tee yield even beyond the yield of the soil application treatments. Thus, foliar spraying of tea plants with Mg-containing solutions can be an effective tool for improving black 
tea yield and quality. Unfortunately, the authors failed to provide information on the micronutrient content of the green leaves so that the tremendous effect of foliar spraying in terms of quality and yield increase can, despite the observed increasing effect on green leaf $\mathrm{Mg}$ concentrations, not be solely ascribed to Mg. Jayanganesh et al. (2011) reported that $\mathrm{MgSO}_{4}$ supply consistently increased secondary metabolites and therefore black tea quality. In contrast, Ruan et al. (1999) found (after conducting a 2-year field trial) for different types of tea (black tea, oolong tea, green tea) that, generally, $\mathrm{Mg}$ had a decreasing effect on the polyphenol content, and only under severe $\mathrm{Mg}$ deficiency polyphenols contents slightly increased. It would be interesting to investigate the effect of $\mathrm{Mg}$ on both primary and secondary metabolism. This may be underlined by some observations made in biotechnological applications, where additional $\mathrm{Mg}$ supply fuelled the production of secondary metabolites (see next sections).

\section{Ornamentals}

Anthocyanins are important constituents for ornamentals as they typically accumulate in vacuoles giving species- and variety-specific colouration to flowers (Markham et al. 2000). Shaked-Sachray et al. (2002) reported that high temperature-enhanced degradation of anthocyanins that give aster (hybrid of Aster ericoides $\times$ Aster pilosus) flowers their characteristic colour is reduced by $\mathrm{Mg}$ application. A direct effect is suggested as the anthocyanin concentration is closely correlated with the $\mathrm{Mg}$ application-enhanced $\mathrm{Mg}$ concentration in the petals. However, apparently this effect was not due to an increasing impact on anthocyanin-synthesizing enzymes like phenylalanine ammonia-lyase or chalcone isomerase. Future research should clarify the role of $\mathrm{Mg}$ in reducing anthocyanin degradation as this could have strong implications for the production of ornamentals with improved and prolonged colouration.

Magnesium in biotechnology

Hairy root cultures are common in research and are used as model system for transgenic studies. Such a model system, however, could also serve as production system for specific compounds. The advantage of such a growth system is its genetic stability, its stable universal and specific metabolism and its unlimited growth on media. Hank et al. (2003) report that increased $\mathrm{MgSO}_{4}$ application to genetically modified root cultures of the herbaceous plant species belladonna (Atropa belladonna L.), which is produced for the production of tropane alkaloids for medicinal applications, positively affected growth and tropane alkaloid production. Szöke et al. (2004) found that $\mathrm{MgSO}_{4}$ supply to chamomile (Matricaria recutita L., formerly Chamomilla recutita $L$.) root culture (widely known in classical and folk medicine for its contents in essential oils) positively affected not only growth of the root cultures (genetically modified hairy root and wild-type cultures) but also improved the quality and quantity of essential oil production. Both studies intended to improve methodologies in biotechnology. Future research should also focus on the underlying mechanisms as the outcomes could (1) give new insights into the role of $\mathrm{Mg}$ in plant physiology, e.g. the physiology of secondary plant metabolites (underlined by the interesting results on the effect of $\mathrm{Mg}$ supply on the phenol metabolism of tea) and (2) enhance the efficiency of biotechnological approaches developed for the production of essential and health promoting metabolites, without impairing rare herbaceous species in their natural environment.

\section{Mg response of yield versus quality: is the quality improved beyond Mg supply adequate for maximum yield}

In the previous sections emphasis was given to the impact of Mg supply on the quality of agricultural and horticultural produce. However, for practical considerations the crucial question is whether the $\mathrm{Mg}$ requirement for maximum quality is already met by application levels necessary for obtaining maximal yield, or whether the quality response to $\mathrm{Mg}$ deserves particular attention in its own right as the quality is still improved beyond the yield maximum. In the following table those articles reporting both the yield and the quality response to $\mathrm{Mg}$ supply have been analysed in this regard, provided that either a yield plateau was reached, or that yield was still positively responding to increasing $\mathrm{Mg}$ supply while quality attributes levelled off already.

This meta-analysis clearly proves that beneficial effects of $\mathrm{Mg}$ application on crop quality beyond 
those rates required for obtaining maximum yields are rarely observed (Table 3 ). With respect to practical consequences it is concluded that growers should ensure adequate $\mathrm{Mg}$ supply required for maximum - or optimal economic - yield, which at the same time will ensure optimal crop quality in virtually all cases.

\section{Conclusions}

Despite the well-known fundamental roles of $\mathrm{Mg}$ in plant metabolism, the number of studies addressing the significance of $\mathrm{Mg}$ for the quality of agricultural and horticultural produce appears very limited as compared to other major nutrients. Most published studies either do not address $\mathrm{Mg}$ responses specifically, and/or remain rather descriptive not illuminating the biochemical and physiological mechanisms underlying the response of the various quality parameters. These generalisations do not apply to potato and tea, where due to the economic importance of their complex quality indices a number of detailed studies have been carried out. Among fruits and vegetables apples and tomatoes appear to be the most intensively studied crops. However, decisive quality parameters important for horticultural crops like TSS and acidity are often more closely correlated with cation ratios, e.g. $\mathrm{Ca} / \mathrm{Mg}$ and $\mathrm{K} / \mathrm{Mg}$ rather than with $\mathrm{Mg}$ concentrations alone. Despite the rare studies on horticultural crops the following conclusions can be drawn: (1) The $\mathrm{Mg} / \mathrm{Ca}$ ratio mainly determines the functional properties, and service and stability aspects as components of the total food quality, such as product firmness, texture and storability that are mainly determined by the role of $\mathrm{Ca}$ in stabilizing cell walls. Since $\mathrm{Mg}$ is capable of replacing $\mathrm{Ca}$ from binding sites, imbalanced $\mathrm{Ca} / \mathrm{Mg}$ ratios in the tissue often negatively affect product quality. (2) The $\mathrm{Mg} / \mathrm{K}$ ratio on the other hand appears to influence primarily organoleptic properties through the role of both mobile cations in the regulation of (i) cellular cation/anion balances and organic acid (TA) accumulation, and internal $\mathrm{pH}$ and (ii) source-sink relationships. Juice acidity and TA may to a certain degree be influenced by the cation/anion ratio, whereas TSS or the content of valuable amino acids in harvested organs is a consequence of metabolitetranslocating processes. In conclusion, $\mathrm{Mg}$ is to be considered the forgotten element. This does not only apply to the nutrient management in the field and the
Table 3 A meta-analysis of the $\mathrm{Mg}$ requirement for maximum yield as compared to the response of quality aonly a few quality parameters positively affected beyond the dose required for maximum yield

\begin{tabular}{|c|c|c|c|c|}
\hline \multirow[t]{2}{*}{$\begin{array}{l}\text { Crop, mode of } \mathrm{Mg} \\
\text { application }\end{array}$} & \multicolumn{3}{|c|}{$\begin{array}{l}\text { Quality is improved } \\
\text { at Mg doses beyond } \\
\text { the supply required } \\
\text { for maximum yield? }\end{array}$} & \multirow[t]{2}{*}{ Reference } \\
\hline & No & Partly $^{\mathrm{a}}$ & Yes & \\
\hline Winter wheat, soil & $\mathrm{X}$ & & & Chwil (2009) \\
\hline Sugar beet, soil & $\mathrm{X}$ & & & Barlog et al. (2002), Villarias et al. (2000) \\
\hline Sugar beet, foliar & $\mathrm{X}$ & & & $\begin{array}{l}\text { Barlog and Grzebisz (2001), Gutmanski et } \\
\text { al. (1998) }\end{array}$ \\
\hline Sugar beet, foliar & & $\mathrm{X}$ & & Kristek et al. (2000) \\
\hline Potato - late industrial, soil & $\mathrm{X}$ & & & Cepl (1994) \\
\hline Potato, soil & & & $\mathrm{X}$ & Klein et al. (1981) \\
\hline Spring rapeseed, soil & $\mathrm{X}$ & & & Bogdevich and Mishuk (2006) \\
\hline Oil mustard, soil & $\mathrm{X}$ & & & Jahangir et al. (2005) \\
\hline Oil palm, soil & $\mathrm{X}$ & & & Tang et al. (2001) \\
\hline Oil palm, soil & & & $\mathrm{X}$ & Tayeb (2005) \\
\hline Groundnut, soil & $\mathrm{X}$ & & & Rajan et al. (1984) \\
\hline Sunflower, soil & $\mathrm{X}$ & & & Ahmedkhan et al. (1990) \\
\hline Cabbage, nutrient solution & $\mathrm{X}$ & & & Hara and Sonoda (1981) \\
\hline Citrus, sand culture & $\mathrm{X}$ & & & Moss and Higgins (1974) \\
\hline Apple, not specified & $\mathrm{X}$ & & & Bramlage et al. (1980), Marcelle (1995) \\
\hline
\end{tabular}


number of studies addressing Mg-related responses of crop performance, but also to the intensity at which scientific studies address issues of crop quality as affected by Mg supply. There is still need for a comprehensive evaluation of the role of $\mathrm{Mg}$ in quality formation.

Acknowledgments In this review the authors refer to published studies on the significance of $\mathrm{Mg}$ supply on product quality in agricultural and horticultural crops. Even though we tried to cover the existing literature in this area, we apologize should we have overlooked relevant publications in this review and are grateful for bringing those to our attention.

Open Access This article is distributed under the terms of the Creative Commons Attribution License which permits any use, distribution, and reproduction in any medium, provided the original author(s) and the source are credited.

\section{References}

Affleck I, Sullivan JA, Tarn R, Yada R (2012) Stability of eight potato genotypes for sugar content and French fry quality at harvest and after storage. Can J Plant Sci 92:87-96

Ahmedkhan T, Venugopal K, Devaiah C, Seenappa K (1990) Effect of secondary nutrients and boron on some growth characters and yield in sunflower. J Oilseeds Res 7:136-139

Al'shevskii NG, Derebon YG (1982) Effect of magnesium fertilizers on yield and quality of winter wheat. Khimiya v Sel'skom Khozyaistve 4:17-20

Alcaraz-Lopez C, Botia M, Alcaraz CF, Riquelme F (2003) Effects of foliar sprays containing calcium, magnesium and titanium on plum (Prunus domestica L.) fruit quality. J Plant Physiol 160:1441-1446

Alcaraz-Lopez C, Botia M, Alcaraz CF, Riquelme F (2004) Effects of foliar sprays containing calcium, magnesium and titanium on plum (Prunus persica $\mathrm{L}$.) fruit quality. J Sci Food Agric 84:949-954

Allison MF, Jaggard KW, Armstrong MJ (1994) Time of application and chemical form of potassium, phosphorus, magnesium and sodium fertilizers and effects on growth, yield and quality of sugarbeet (Beta vulgaris). J Agric Sci 123:61-70

Allison MF, Fowler JH, Allen EJ (2001) Responses of potato (Solanum tuberosum) to potassium fertilizers. J Agric Sci 136:407-426

Askew HO, Chittenden ET, Monk RJ, Watson J (1960) Chemical investigations on bitter pit of apples. New Zeal J Agr Res 3:169-178

Azizi K, Yaghobi M, Hidary S, Chaeichi MR, Roham R (2011) Effects of different methods of magnesium sulphate application on qualitative and quantitative yield of lentil (Lens culinaris Medik.) cultivars under Khorramabad climatic conditions of Iran. Res Crops 12:103-111

Barlog P, Grzebisz W (2001) Effect of magnesium foliar application on the yield and quality of sugar beet roots. Rostlinna Vyroba 47:418-422

Barlog P, Grzebisz W (2004) Sugar beet fertilization with potassium, sodium and magnesium-yielding and diagnostic evaluation Part II. Quality of roots and yield of sugar. Biuletyn Instytutu Hodowli I Aklimatyzacji Roslin 234:83-92

Barlog P, Grzebisz W, Paradowski A (2002) Effect of potassium, sodium and magnesium fertilization on yielding of three sugar beet varieties part I. Yields of root and sugar. Biuletyn Instytutu Hodowli I Aklimatyzacji Roslin 222:119-126

Beringer H, Forster H (1981) Einfluß variierter Mg-Ernährung auf Tausendkorngewicht und P-Fraktionen des Gerstenkorns. Z Pflanzenernähr Bodenkd 144:8-15

Bogdevich IM, Mishuk OL (2006) Efficiency of magnesium and sulfur-containing fertilizers under spring rape seed on the podzoluvisol loam soil with different magnesium content. Proc Natl Acad Sci Belarus Agrarian Sci Ser 2:68-72

Bohn T, Davidsson L, Walczyk T, Hurrell RF (2004) Phytic acid added to white-wheat bread inhibits fractional apparent magnesium absorption in humans. Am J Clin Nutr 79:418-423

Borkowski J, Szwonek E (1986) Effect of potassium and magnesium on the quality of tomato fruits. Acta Hort 191:133-139

Bramlage WJ, Drake M, Lord WJ (1980) The influence of mineral nutrition on the quality and storage performance of pome fruits in North America. Acta Hort 92:29-40

Broadley MR, White PJ (2010) Eats roots and leaves. Can edible horticultural crops address dietary calcium, magnesium and potassium deficiencies? Proc Nutr Soc 69:601-612

Buchholz K, Märländer B, Puke H, Glattkowski H, Thielecke K (1995) Neubewertung des technischen Wertes von Zuckerrüben. Zuckerind 120:113-121

Burmeister DM, Dilley DR (1991) Induction of bitter pit-like symptoms on apples by infiltration with $\mathrm{Mg}^{2+}$ is attenuated by $\mathrm{Ca}^{2+}$. Postharvest Biol Tech 1:11-17

Burmeister DM, Dilley DR (1993) Characterization of $\mathrm{Mg}^{2+}$-induced bitter pit-like symptoms on apples: a model system to study bitter pit initiation and development. J Agric Food Chem 41:1203-1207

Cakmak I, Kirkby EA (2008) Role of magnesium in carbon partitioning and alleviating photooxidative damage. Physiol Plant 133:692-704

Cakmak I, Hengeler C, Marschner H (1994) Partitioning of shoot and root dry matter and carbohydrates in bean plants suffering from phosphorus, potassium and magnesium deficiency. J Exp Bot 45:1245-1250

Cepl J (1994) Analysis of the effect of potassium and magnesium fertilization on some indicators of the potato yield and quality. Rostlinna Vyroba 40:899-905

Chapagain BP, Wiesman Z (2004) Effect of potassium magnesium chloride in the fertigation solution as partial source of potassium on growth, yield and quality of greenhouse tomato. Scientia Hort 99:279-288

Chwil S (2001) Wpływ dolistnego i doglebowego stosowania magnezu na wielkość i strukturę plonu pszenicy ozimej. Biul Magnezol 6:118-124

Chwil S (2009) Oddziaływanie magnezu i azotu na cechy jakościowe plonu pszenicy ozimej. Ann Universitat Maria Curie Skłodowska Lublin-Polonia 64:61-66

Csengeri P, Kozak M (1985a) Effect of calcium and magnesium fertilizer on yield and oil content in sunflowers. XV. A mezogazdasag kemizalasa konferencia es kiallitas 149-150

Csepregi P, Kozak M (1985) Response of sunflowers to fertilizer on acid Mg-deficient sandy soil. Olaj Szappan Kozmetika 34:103-105 
Davies JN, Winsor GW (1967) Effect of nitrogen, phosphorus, potassium, magnesium and liming on the composition of tomato fruit. J Sci Food Agric 18:459-466

Delgado E, Sulaiman MI, Pawelzik E (2001) Importance of chlorogenic acid on the oxidative potential of potato tubers of two German cultivars. Potato Res 44:207-218

Deliboran A, Sakin E, Aslan H, Mermut A (2011) Effects of different water, phosphorus and magnesium doses on the quality and yield factors of soybean (Glycine $\max$ L.) in Harran plain conditions. Int J Phys Sci 6:1484-1495

Ding Y, Luo W, Xu G (2006) Characterisation of magnesium nutrition and interaction of magnesium and potassium in rice. Ann Appl Biol 149:111-123

Draycott AP, Farley RF (1971) Effect of sodium and magnesium fertilisers and irrigation on growth, composition and yield of sugar beet. J Sci Food Agr 22:559-563

Dris R, Niskanen R, Fallahi E (1999) Relationships between leaf and fruit minerals and fruit quality attributes of apples grown under northern conditions. J Plant Nutr 22:1839-1851

El-Gazzar AAM (2000) Effect of fertilization with nitrogen, potassium and magnesium on 'Anna' apples: 3 - effect of Mg fertilization. Ann Agr Sci (Cairo) 3:1161-1168

El-Sayed GS (2005) Effect of nitrogen and magnesium fertilization on yield and quality of two sugar beet varieties. Egypt J Agr Res 83:709-724

Evans D, Mondy NI (1984) Effect of magnesium fertilization on glycoalkaloid formation in potato tubers. J Agric Food Chem 32:465-466

Fecenko J, Francakova H (1980) Effect of magnesium fertilization on the nitrogen compounds of spring barley. Pol'nohospodarstvo 26:700-706

Feltran JC, Lemos LB, Vieites RL (2004) Technological quality and utilization of potato tubers. Sci Agr (Piracicaba, Braz) 61:593-597

Finck S (1992) Physiologische und strukturelle Veränderungen an Bäumen unter Magnesiummangel. In: Glatzel G, Jandel R, Sieghardt M, Hager H (eds). Magnesiummangel in mitteleuropäischen Waldökosystemen. Forstliche Schriftenreihe Band 5, Universität für Bodenkultur Wien, pp 16-26

Fischer ES, Lohaus G, Heineke D, Heldt HW (1998) Magnesium deficiency results in accumulation of carbohydrates and amino acids in source and sink leaves of spinach. Physiol Plant 102:16-20

Garman P, Mathis WT (1956) Studies of mineral balance as related to Baldwin Spot in Connecticut. Connecticut Agricultural Experiment Station Bulletin 601

Gerendás J, Heuser F, Sattelmacher B (2007) Influence of nitrogen and potassium supply on contents of acrylamide precursors in potato tubers and on acrylamide accumulation in French fries. J Plant Nutr 30:1499-1516

Gibson RS, Bailey KB, Gibbs M, Ferguson EL (2010) A review of phytate, iron, zinc, and calcium concentrations in plantbased complementary foods used in low-income countries and implications for bioavailability. Food Nutr Bull 31 (Supplement):S134-S146

Giusti AM, Bignetti E, Cannella C (2008) Exploring new frontiers in total food quality definition and assessment: from chemical to neurochemical properties. Food Bioproc Technol 1:130-142

Gransee A, Führs H (2013) Magnesium mobility in soils as challenge for soil and plant analysis, magnesium fertilization and root uptake under adverse growth conditions. Plant Soil. doi:10.1007/s11104-012-1567-y

Greenwood DJ, Hunt J (1986) Effect of nitrogen fertiliser on the nitrate contents of field vegetables grown in Britain. J Sci Food Agric 37:373-383

Greffeuille V, Abecassis J, Lapierre C, Lullien-Pellerin V (2006) Bran size distribution at milling and mechanical and biochemical characterization of common wheat grain outer layers: a relationship assessment. Cereal Chem 83:641-646

Grzebisz W (2013) Crop response to magnesium fertilization as affected by nitrogen supply. Plant Soil. doi:10.1007/ s11104-012-1574-Z

Gull D, Isenberg FM (1960) Chlorophyll and solanine content and distribution in four varieties of potato tubers. Proc Am Soc Hortic Sci 75:545-556

Gutmanski I, Nowakowski M, Szymczak-Nowak J (1998) The influence of the fertilizer Kamex Gran, potassium salt and magnesium sulphate on the amount, processing quality and health of sugar beet. Folia universitatis agriculturae stetinensis. Agricultura 72:101-108

Han D-F, Wang D-H, Huang P-Z, Duan J-X, Ge R-S, Zhou W-L (2010) Effects of different morphology magnesium on yield and quality of 'Zaoshu 5' Chinese cabbage. Acta Hort Sin 37:1655-1660

Hank H, László I, Bálványos I, Tóth E (2003) Effect of magnesium on the growth and alkaloid production of hairy root cultures. Acta Hort 597:271-274

Hao X, Papadopoulos AP (2003) Effects of calcium and magnesium on growth, fruit yield and quality in a fall greenhouse tomato crop grown on rockwool. Can J Plant Sci 83:903-912

Hao X, Papadopoulos AP (2004) Effects of calcium and magnesium on plant growth, biomass partitioning, and fruit yield of winter greenhouse tomato. Hort Sci 39:512-515

Hara T, Sonoda Y (1981) The role of macronutrients in cabbagehead formation-II: contribution to cabbage-head formation of calcium, magnesium or sulfur supplied at different growth stages. Soil Sci Plant Nutr 27:45-54

Hartz TK, Miyao G, Mullen RJ, Cahn MD, Valencia J, Brittan KL (1999) Potassium requirements for maximum yield and fruit quality of processing tomato. J Amer Soc Hort Sci 124:199-204

Hermans C, Johnson GN, Strasser RJ, Verbruggen N (2004) Physiological characterisation of magnesium deficiency in sugar beet: acclimation to low magnesium differentially affects photosystems I and II. Planta 220:344-355

Hermans C, Bourgis F, Faucher M, Delrot S, Strasser RJ, Verbruggen N (2005) Magnesium deficiency in sugar beet alters sugar partitioning and phloem loading in young mature leaves. Planta 220:441-449

Hiltrop P (1999) Rohstoffqualitäten für Pommes frites und andere vorgebackene Kartoffelprodukte. In: Schuhmann P (ed) Die Erzeugung von Kartoffeln zur industriellen Verarbeitung. Agrimedia $\mathrm{GmbH}$, Bergen

Huyskens-Keil S, Schreiner M (2003) Quality of fruits and vegetables. J Appl Bot 77:147-151

International Organization for Standardization (2005) ISO 9000:2005: Quality management systems-Fundamentals and vocabulary. http://www.iso.org/iso/home/standards/ management-standards/iso_9000.htm?archive=all\#newslist

Jahangir AA, Afroz RS, Latif A, Sarker MAM, Haq SMI (2005) Response of mustard to $\mathrm{Mg}$ and $\mathrm{S}$ fertilization. Bangladesh J Sci Ind Res 40:115-122 
Jayaganesh S, Venkatesan S (2010) Impact of magnesium sulphate on biochemical and quality constituents of black tea. Amer J Food Tech 5:31-39

Jayanganesh S, Venkatesan S, Senthurpandian VK (2011) Impact of different sources and doses of magnesium fertilizer on biochemical constituents and quality parameters of Black Tea. Asian J Biochem 6:273-281

Kaack K, Pedersen HL (2011) Modelling of the optimum harvest time for long-term storage of 'Elstar' and 'Aroma' (Malus domestica) apples at low oxygen concentration. Acta Agr Scan Sect B Plant Soil 61:565-572

Kader AA (1998) Flavor Quality of fruits. In: Management of fruit ripening. AA Kader (Ed) Postharvest horticulture series no. 9. Postharvest outreach program, Department of Pomology, University of California, Davis

Karikha AJ, Dudgeon LT, Hauck HM (1944) Influence of variety, location, fertilizer and storage on the ascorbic acid content of potatoes grown in New York State. J Agric Res 68:49

Klein LB, Chandra S, Mondy NI (1981) Effect of magnesium fertilization on the quality of potatoes: yield, discolouration, phenols, and lipids. J Agric Food Chem 29:384-387

Klein LB, Chandra S, Mondy NI (1982) Effect of magnesium fertilization on the quality of potatoes: total nitrogen, nonprotein nitrogen, protein, amino acids, minerals, and firmness. J Agric Food Chem 30:754-757

Kolbe H, Müller K, Olteanu G, Gorea T (1995) Effects of nitrogen, phosphorus and potassium fertilizer treatments on weight loss and changes in chemical composition of potato tubers stored at $4{ }^{\circ} \mathrm{C}$. Potato Res 38:97-107

Koo RC (1971) A comparison of magnesium sources for citrus. Proc Soil Crop Soc Florida 31:137-140

Kottur G, Venkatesan S, Kumar RSS, Murugesan S (2010) Diversity among various forms of catechins and its synthesizing enzyme (phenylalanine ammonia lyase) in relation to quality and black tea (Camellia ssp). J Sci Food Agr 90:1533-1537

Kovacevic V, Vukadinovic V, Komljenovic I (1991) Tipovi kloroze soje uslijed debalansa ishrane na tlime istocne Hrvatske. Znan Prak Poljopr Technol 21:15-23

Kramer A, Twigg BA (1970) Quality control for the food industry, vol 1. Fundamentals, 3rd ed. Westport. AVI

Kristek A, Kovacevic V, Antunovic M (2000) Response sugar beet to foliar magnesium fertilization with Epsom salt. Rostlinna Vyroba 46:147-152

Kristek A, Antunovic M, Brkic S, Kanisek J (2003) The influence of boron and magnesium foliar fertilization on elements of sugar beet yield. Listy Cukrovarnicke a Reparske 119:106-108

Kumar PVS, Basheer S, Ravi R, Thakur MS (2011) Comparative assessment of tea quality by various analytical and sensory methods with emphasis on tea polyphenols. J Food Sci Tech 48:440-446

Lean IJ, DeGaris PJ, McNeil DM, Block E (2006) Hypocalcaemia in dairy cows: meta-analysis and dietary cation anion difference theory revisited. J Dairy Sci 89:669-684

Liu H, Chen X, Chen R, Song S, Sun G (2008) Effects of magnesium deficiency on growth and photosynthesis of flowering Chinese cabbage. Acta Hort 767:169-174

Love SL, Herrman TJ, Thomson-Johns A, Baker TP (1994) Effect and interaction of crop management factors on the glycoalkaloid concentration of potato tubers. Potato Res 37:77-85

Lujan L, Smith O (1964) Potato quality XXIV. Objective measurement of mealiness in potato. Am Potato J 41:244252

Lulai EC, Orr PH (1979) Influence of potato specific gravity on yield and oil content of chips. Am Potato J 56:379-390

MaL, Ruan YY, Han W, Shi Y (2005) Effect of magnesium nutrition on the formation and transport of free amino acids in tea plants. Proceedings of the International Symposium on Innovation in Tea Science and Sustainable Development in Tea Industry 10-15, Rea Research Institute, Chinese Academy of Agricultural Sciences, Hangzhou, China, 151-158

Maga JA, Fitzpatrick TJ (1980) Potato alkaloids. CRC Crit Rev Food Sci Nutr 12:371-405

Magnitskii KP, Sokolova VA, Zhukov SN (1970) Effect of Mg fertilizers on yield and quality of winter rye. Khimiya $\mathrm{V}$ Sel'skom Khozyaistve 8:565-568

Malundo TMM, Shewfelt RL, Scott JW (1995) Flavor quality of fresh tomato (Lycopersicon esculentum Mill.) as affected by sugar and acid levels. Post Biol Tech 6:103-110

Marcelle RD (1995) Mineral nutrition and fruit quality. Acta Hort 383:219-226

Markham KR, Gould KS, Winefield CS, Mitchell KA, Bloor SJ, Boase MR (2000) Anthocyanic vacuolar inclusions - their nature and significance in flower colouration. Phytochem 55:327-336

Marschner P (ed) (2012) Marschner's Mineral Nutrition of Higher Plants (Third Edition). Elsevier Ltd

McKenzie RH, Bremer E, Grant CA, Johnston AM, DeMulder J, Middleton AB (2006) In-crop application of nitrogen fertilizer on grain protein concentration of spring wheat in the Canadian prairies. Can J Soil Sci 86:565-572

McMillan M, Thompson JCQ (1979) Outbreak of suspected solanine poisoning in schoolboys - examination of criteria of solanine poisoning. Quart J Med 48:227-243

Miguel MG (2011) Anthocyanins: antioxidant and/or antiinflammatory activities. J Appl Pharmaceut Sci 01:7-15

Milner SE, Brunton NP, Jones PW, O’ Brien NM, Collins SG, Maguire AR (2011) Bioactivities of glycoalkaloids and their aglycones from solanum species. J Agric Food Chem 59:3454-3484

Mondy NI, Koch RL (1978) Influence of nitrogen fertilization on potato discoloration in relation to chemical composition. I. Lipid, potassium and dry matter content. J Agric Food Chem 26:666-669

Mondy NI, Ponnampalam R (1985) Effect of magnesium fertilizers on total glycoalkaloids and nitrate- $\mathrm{N}$ in Katahdin tubers. J Food Sci 50:535-536

Mondy NI, Ponnampalam R (1986) Potato quality as affected by source of magnesium fertilizer: nitrogen, minerals, and ascorbic acid. J Food Sci 51:352-354

Mondy NI, Bourne A, Breslow B, Mattick LR (1965) The effect of boron on the lipid content and discoloration of potatoes. J Food Sci 30:1-6

Mondy NI, Owens Mobley E, Bond Gedde-Dahl S (1967) Influence of potassium fertilization on enzymatic activity, phenolic content and discolouration of potatoes. J Food Sci 32:378-381

Moretti G (2002) Effect of foliar treatments of magnesium, manganese, and zinc on grafted vines in the nursery. Acta Hort 594:647-652 
Morton AR, Trolove SN, Kerckhoffs LHJ (2008) Magnesium deficiency in citrus grown in the Gisborne district of New Zealand. New Zeal J Crop Hort Sci 36:199-213

Moss GI, Higgins ML (1974) Magnesium influences on the fruit quality of sweet orange (Citrus sinensis L. Osbeck). Plant Soil 41:103-112

Mottram DS, Wedzicha BL, Dodson AT (2002) Acrylamid is formed in the Maillard reaction. Nature 419:448-449

Moustafa ZR, Omran SEH (2006) Effect of foliar spray with boron or magnesium in combination with nitrogen fertilization on sugar beet plants. Egypt J Soil Sci 46:115-129

Mozafar A (1993) Nitrogen fertilizers and the amount of vitamins in plants: a review. J Plant Nutr 16:2479-2506

Mulder EG (1949) Mineral nutrition in relation to the biochemistry and physiology of potatoes. Plant Soil 2:59-121

Muneta P (1981) Comparisons of inhibitors of tyrosine oxidation in the enzymatic blackening of potatoes. Amer J Potato Res 58:85-92

Nelson WL, Burkhart L, Colwell WE (1945) Fruit development, seed quality, chemical composition, and yield of soybeans as affected by potassium and magnesium. Soil Sci Soc Am Proc 10:224-229

Noctor G, Foyer CH (1998) Ascorbate and glutathione: keeping active oxygen under control. Annu Rev Plant Physiol Plant Mol Biol 49:249-279

Noè N, Eccher T, Stainer R, Porro D (1995) Influence of nitrogen, potassium and magnesium fertilization on fruit quality and storability of Golden Delicious apples. Acta Hort 383:439-447

Nzanza B (2006) Yield and quality of tomato as influenced by differential $\mathrm{Ca}, \mathrm{Mg}$ and $\mathrm{K}$ nutrition. MSc thesis, Conducted at the Department of Plant Production and Soil Science in the Faculty of natural and Agricultural Sciences, University of Pretoria, Pretoria. (http://upetd. up.ac.za/thesis/available/etd-05152008-144742/unre stricted/dissertation.pdf)

Ochs R, Ollagnier M (1977) Effet des engrais sur la composition des lipids produits par les oléagineux tropicaux pérennes et sur leur rendement. Oléagineux 32:409-426

Okal AW, Owuor PO, Kamau DM, Mang'uro LOA (2012) Effects of production locations and plucking intervals on clonal tea fatty acid levels in the Kenya highlands. Food Sci Tech Res 18:351-356

Osman MSH (2005) Effect of potassium and magnesium on yield and quality of two sugarbeet varieties. Egypt J Agr Res 83:215-228

Poberezny J, Wszelaczynska E (2011) Effect of bioelements (N, $\mathrm{K}, \mathrm{Mg}$ ) and long-term storage of potato tubers on quantitative and qualitative losses Part II. Content of dry matter and starch. J Elem 16:237-246

Portis AR Jr, Salvucci ME, Ogren WL (1986) Activation of Ribulosebisphosphate Carboxylase/Oxygenase at physiological $\mathrm{CO} 2$ and ribulosebisphosphate concentrations by Rubisco activase. Plant Physiol 82:967-971

Py C, Lacoeuilhe JJ, Teisson C (1987) The Pineapple: Cultivation and Uses. Editions GP Maisonneuue and Larose, Paris, $\mathrm{p}$ 188-191

Quaggio JA, Sobrinho JT, Dechen AR (1992) Magnesium influences on fruit yield and quality of 'Valencia' sweet orange on Rangpur lime. Proc Int Soc Citricult 2:633-637
Rabiei V, Shirzadeh E, Angourani HR, Sharafi Y (2011) Effect of thyme and lavender essential oils on the qualitative and quantitative traits and storage life of apple 'Jonagold' cultivar. J Med Plant Res 5:5522-5527

Rajan MSS, Murthy PK, Rao RS, Rao RS (1984) Oil output as influenced by the application of potassium, calcium and magnesium to groundnut. Madras Agric J 71:411-412

Ram RA, Bose TK (2000) Effect of foliar application of magnesium and micronutrients on growth, yield and fruit quality of mandarin orange (Citrus reticulate Blanco). Indian J Hort 57:215-220

Ramos MJM, Monnerat PH, De Rocha Pinho LG, De Carvalho AJC (2010) Sensorial quality of pineapple fruits cultivated in macronutrient and boron deficiencies. Rev Bras Frutic Jaboticabal 32:692-699

Reay PF, Fletcher RH, Thomas VJ (1998) Chlorophylls, carotentoids and anthocyanin concentrations in the skin of 'Gala' apples during maturation and the influence of foliar application of nitrogen and magnesium. J Sci Food Agric 76:63-71

Rogozinska I, Wojdyla T (1999) Der Einfluß variierter Düngung, einer Pflanzenschutz-Anwendung und der Lagerung auf den Glykoalkaloid-Gehalt in Kartoffelknollen zweier Sorten. Potato Res 42:79-88

Römheld V, Kirkby EA (2007) Magnesium functions in crop nutrition and yield. Proceedings of a Confernce in Cambridge (7th Dec. 2007), 151-171

Rosanoff A (2012) Changing crop magnesium concentrationsImpact on human health. Plant Soil. doi:10.1007/s11104012-1471-5

Ruan JY, Wu X, Ye Y, Härdter R (1998) Effect of potassium, magnesium and sulphur applied in different forms of fertilizers on free amino acid content in leaves of tea (Camellia sinensis L.). J Sci Food Agric 76:389-396

Ruan J, Wu X, Härdter R (1999) Effects of potassium and magnesium nutrition on the quality components of different types of tea. J Sci Food Agric 79:47-52

Ruan J, Ma L, Yang Y (2012) Magnesium nutrition on accumulation and transport of amino acids in tea plants. J Sci Food Agric. 92:1375-1383

Rubanov VS, Voitova AS (1970) Action of magnesium fertilizers on the yield and quality of potatoes. Khim Sel Khoz $8: 411$

Rupp D, Fox R, Tränkle L (2002) Foliar application of magnesium fertilizer in grapevines: effects on wine quality. Acta Hort 594:149-155

Sagare BN, Guhe YS, Atre AH (1990) Yield and nutrient harvest by sunflower (Helianthus annuus L.) in response to sulphur and magnesium application in Typic Chromusterts. Annal Plant Physiol 4:15-21

Schlemmer U, Frolich W, Prieto RM, Grases F (2009) Phytate in foods and significance for humans: food sources, intake, processing, bioavailability, protective role and analysis. Mol Nutr Food Res 53:S330-S375

Schuphan W (1961) Zur Qualität der Nahrungspflanzen. BLV Verlagsgesellschaft, pp 170

Serrano M, Martinez-Romero D, Castillo S, Guillén F, Valero D (2004) Effect of preharvest sprays containing calcium, magnesium and titanium on the quality of peaches and nectarines at harvest and during postharvest storage. J Sci Food Agric 84:1270-1276 
Shaked-Sachray L, Weiss D, Reuveni M, Nissim-Levi A, OrenShamir M (2002) Increased anthocyanin accumulation in aster flowers at elevated temperatures due to magnesium treatment. Physiol Plant 114:559-565

Shaul O (2002) Magnesium transport and function in plants: the tip of the iceberg. BioMetals 15:309-323

Shaul O, Hilgemann DW, Almeida-Engler J, Van Montagu M, Inzé D, Galili G (1999) Cloning and characterization of a novel $\mathrm{Mg}^{2+} / \mathrm{H}^{+}$exchanger. EMBO J 67:3456-3462

Shewfeld R, Brückner B (eds) (2000) Fruit and vegetable quality: an integrated view. Technomic Publishing INC, Lancaster Pennsylvania

Shewfelt R (1999) What is quality? Postharvest Biol Technol 15:197-200

Sinden SL, Deahl KL, Aulenbach BB (1976) Effect of glycoalkaloids and phenolics on potato flavour. Food Sci 41:520-523

Sinilal B, Ovadia R, Nissim-Levi A, Perl A, Carmeli-Weissberg M, Oren-Shamir M (2011) Increased accumulation and decreased catabolism of anthocyanins in red grape cell suspension culture following magnesium treatment. Planta 234:61-71

Smith O (1977) "Potatoes: Production, Storing, Processing", 2nd ed.; Avi Publishing Co.: Westport, CT, 1977, Chapter 19, pp 606-607

Sreedhara A, Cowan JA (2002) Structural and catalytic roles for divalent magnesium in nucleic acid biochemistry. BioMetals 15:211-223

Stefanini M, Porro D, Corazzina E, Bastianel A (1994) Magnesium fertilization of vines under Mediterranean conditions. Vignevini 21:29-32

Stevens MA, Kader AA, Albright M (1979) Potential for increasing tomato flavour via increased sugar and acid content. J Amer Soc Hort Sci 104:40-42

Strnad P, Javurek M (1991) Dependence of yield formation and sugar beet quality on nutrient uptake. Rostl Vyr 37:405-412

Sugiyama T, Matsumoto C, Akazawa T (1969) Structure and function of chloroplast proteins-VII. Ribulose-1,5-Diphosphate Carboxylase of Chlorella ellipsoida. Arch Biochem Biophys 129:597-602

Szczepaniak W, Grzebisz W, Zuchlinska B (2002) The response of sugar beet to nitrogen fertilizers in relation to potassiumsodium-magnesium fertilization. Biuletyn Instytutu Hodowli I Aklimatyzacji Roslin 222:83-90

Szöke É, Máday E, Kiss SA, Sonnewend L, Lemberkovics É (2004) Effect of magnesium on essential oil formation of genetically transformed and non-transformed Chamomile cultures. J Am Coll Nutr 23:763S-767S

Talburt W, Smith O (1987) Potato processing, 4th edn. AVI-Van Nostrand Reinhold Company, New York

Tang MK, Nazeeb M, Loong SG (2001) Proceedings of the PIPOC 2001 International Palm Oil Congress. Malaysian Palm Oil Board, Kuala Lumpur, pp 261-271

Tayeb MD (2005) Importance of magnesium in oil palm nutrition. Proceedings of the PIPOC 2005 International Palm
Oil Congress. Malaysian Palm Oil Board, Kuala Lumpur, pp 236-254

Taylor TC, Andersson I (1996) Structural transitions during activation and ligand binding in hexadecameric Rubisco inferred from crystal structure of the activated unliganded spinach enzyme. Nat Struct Biol 3:95-101

Turgeon R (2010) The role of phloem loading reconsidered. Plant Physiol 152:1817-1823

van Rijswijk W, Frewer LJ (2008) Consumer perceptions of food quality and safety and their relation to traceability. Brit Food J 110:1034-1046

Velez-Ramos A, Borges J (1995) Foliar application of nitrogen, potassium and magnesium, and pineapple yield and quality. J Agric Univ P R 79:111-119

Verma RPS, Sarkar B, Gupta R, Varma A (2008) Breeding barley for malting quality improvement in India. Cereal Res Commun 36:135-145

Villarias JL, Garzon E, Ontanon A (2000) Magnesium sulfur fertilizers cultivation beet root. Agricultura Rev Agropecuaria 69(819):676-679

von Bennewitz E, Cooper T, Benavides C, Hlusek J (2011) Response of "Jonagold" apple trees to $\mathrm{Ca}, \mathrm{K}, \mathrm{Mg}$ fertilization in an andisol in southern Chile. J Soil Sci Plant Nutr 11:71-81

Vrataric M, Sudaric A, Kovacevic V, Duvnjak T, Krizmanic M, Mijic A (2006) Response of soybean to foliar fertilization with magnesium sulfate. Cereal Res Comm 34:709712

White PJ, Broadley MR (2009) Biofortification of crops with seven mineral elements often lacking in human dietsiron, zinc, copper, calcium, magnesium, selenium and iodine. New Phytol 182:49-84

Wiesler F, Gerendás J, Sattelmacher B (2003) Influence of mineral fertilizers on nutritional quality of staple food crops. In: Impacts of Agriculture on Human Health and Nutrition, Vol. 1. Encyclopedia of Life Support Systems (EOLSS), http://www.eolss.net/sample-chapters/c10/E5-21-03.pdf

Wszelaczynska E, Poberezny J (2011) Effect of bioelements (N, $\mathrm{K}, \mathrm{Mg}$ ) and long-term storage of potato tubers on quantitative and qualitative losses. Part I. Natural losses. J Elementol 16:135-142

Xu C-J, Guo R-F, Yan H-Z, Yuan J, Yuan G-F, Wang Q-M (2010) Effect of nitrogen fertilization on ascorbic acid, glucoraphinin content and quinone reductase activity in broccoli floret and stem. J Food Agr Environ 8:179-184

Yazaki Y, Asukagawa N, Ishikawa Y, Ohta E, Sakata M (1988) Estimation of cytoplasmic free $\mathrm{Mg}^{2+}$ levels and phosphorylation potentials in mung bean root tips by in vivo ${ }^{31}$ P NMR spectroscopy. Plant Cell Physiol 29:919924

Zengin M, Gökmen F, Gezgin S, Çakmak İ (2008) Effects of different fertilizers with potassium and magnesium on the yield and quality of potato. Asian J Chem 20:663676 